\title{
NATO, AB VE TÜRKIYE: OGSP AÇMAZI
}

\section{Münevver CEBECI $\dot{I}^{*}$}

\section{$\ddot{O ̈ z e t}$}

Bu makalenin amacı, NATO-AB işbirliği ve Türkiye'nin Ortak Güvenlik ve Savunma Politikası'na katılımı ile ilgili açmazı değerlendirmektir. Makalenin ileri sürdü̆̆̈̈ argüman, bu açmazını derinleştiren iki önemli faktör olduğudur. Bunlardan ilki NATO bünyesindeki Avrupacı ayrışmadır. İkinci faktör ise, AB'nin Türkiye'nin adaylık süreci çerçevesinde geliştirmiş olduğu asimetrik tutumu NATO$A B$ işbirliği konularında da sergilemeye çalışmasıdır. Makalenin vardı̆̆ı sonuç; NATO-AB-Türkiye üçgeninde yaşanan açmazın bir an önce çözülmesi gerektiği, ancak, yaşanan sorunların çözümü için sadece Türkiye'yi adres göstermenin doğru olmadiğıdır.

Anahtar kelimeler: NATO-AB İşbirliği, Ortak Güvenlik ve Savunma Politikası (OGSP), Avrupacı ayrışma, Türkiye

\section{NATO, THE EU AND TURKEY: THE CSDP STALEMATE}

\section{Abstract}

The aim of this article is to evaluate the stalemate in NATO-EU cooperation and in the involvement of Turkey in the Common Security and Defence Policy. Its major argument is that there are two factors that deepen this stalemate. The first one is the Europeanist decoupling in NATO. The second one is that the Union tries to pursue the asymmetrical relationship that it has with Turkey within the framework of the country's EU candidacy in the realm of NATO-EU relations. The article concludes that this stalemate should be resolved as soon as possible, nevertheless, it would not be reasonable to point to Turkey, only, for finding a solution to the problem.

Keywords: NATO-EU Cooperation, Common Security and Defence Policy (CSDP), Europeanist decoupling, Turkey

\footnotetext{
* Yard. Doç. Dr., Marmara Üniversitesi, Avrupa Birliği Enstitüsü, AB Siyaseti ve Uluslararası İlişkiler Anabilim Dalı
} 


\section{Giriş}

NATO-AB işbirliği, Türkiye ve Güney Kıbrıs'ın çifte vetosu ve Fransa gibi bazı Avrupacı müttefiklerin uzlaşmaz tutumu nedeni ile bloke durumdadır. Oysa, küresel ekonomik krizin etkisini attırdığı, Avrupa'da savunma bütçelerinin giderek düştüğü ve istikrarsızlığın yaygınlaştığı bu günlerde, NATO-AB işbirliği hem NATO'nun hem de AB'nin geleceği açısından çok önemlidir. Bu makalenin amacı NATO-AB işbirliği ve Türkiye'nin Ortak Güvenlik ve Savunma Politikası'na katılımı ile ilgili açmazı değerlendirmektir. Makalenin ana argümanı, OGSP açmazını derinleştiren iki faktör olduğudur: (1) NATO bünyesindeki Avrupacı ayrışma ve (2) AB'nin Türkiye'nin adaylık süreci çerçevesinde geliştirmiş olduğu asimetrik tutumu NATO-AB işbirliği konularında da sergilemeye çalışması.

NATO içinde, İttifakın kurulduğu ilk yıllardan bu yana süregelen ve Avrupa'nın NATO'dan bağımsız olarak kendi savunma kabiliyetlerini oluşturmasını öngören Avrupalı Müttefiklerin yarattığı bir Avrupacı ayrışma vardır. Bu Avrupacı ayrışma özellikle 2003 Irak savaşı sonrasında kendisini iyice belli etmiştir. Avrupacı Müttefiklerin AB çıkarlarını NATO taahhütlerinin önünde tutmaları ile durum iyice kötüleşmiştir ve bu konu Ortak Güvenlik ve Savunma Politikası (OGSP) açmazına olumsuz yönde ciddi etki yapmaktadır.

Öte yandan, AB, aday ülkelerle kurallarını (hatta derecesini ve hızını) kendisinin belirlediği ve söz konusu ülkelerin uymak zorunda kaldığı bir ilişki biçimi geliştirmiştir. Bunun sebebi, aday ülkelerin $A B$ 'den ricacı konumda olmalarıdır. Ancak, AB aday ülkelerle geliştirdiği bu ilişki biçimini bu ülkelerle adaylık çerçevesi dışında kalan konular konusunda da sergilemeye çalışmaktadır. Bunun temel sebebi AB'nin bu ülkelerle başka çerçeveler dahilinde nasıl bir ilişki kurması gerektiğini hesaplayamaması veya başka şekillerde (kendi lehine asimetrik ilişki şekli dışında) ilişki kurmayı çıkarlarına uygun bulmaması olabilir. NATO-AB ilişkileri ile ilgili olarak Birliğin Türkiye ile yaşadığı sorun tam da budur. NATOAB ilişkilerinde, özellikle NATO imkân ve kabiliyetlerinin kullanılması açısından, AB'nin ricacı konumda olduğu söylenilebilir. NATO kararlarını oybirliği ile almaktadır ve Türkiye'nin NATO'nun AB ile işbirliği konusunda alacağı kararlarda veto hakkı bulunmaktadır. Bu durumda, AB'nin bu mesele özelinde Türkiye'den ricacı konumda olduğunu öne sürmek yanlış olmayacaktır. Dolayısıyla, bu meselede, AB ile ilişkisi açısından, Türkiye lehine bir asimetrik durumdan bahsetmek mümkündür. Oysa $\mathrm{AB}$, bu noktayı görmezden gelip, bu konu ile ilgili olarak da Türkiye ile adaylık çerçevesinde kurmuş olduğu ve kendi lehine asimetrik politikalarını devam ettirmeye çalışmaktadır. $\mathrm{Bu}$ da NATO-AB ilişkilerindeki OGSP açmazını derinleştirmektedir.

Makalede, ilk olarak, meselenin temelinde yatan, BAB'in feshedilmesiyle Türkiye'nin kaybetmiş olduğu Ortak Üyelik haklarının Avrupa Güvenlik ve Savunma Politikası (AGSP) çerçevesinde yeteri şekilde ikame edilmemiş olması durumu irdelenmektedir. Sonraki bölümlerde, Berlin Artı işbirliği düzenlemeleri ve sonrasında yaşanan açmaz ele alınmaktadır. İzleyen bölümde, NATO içindeki Avrupacı ayrışma analiz edilmektedir. Son olarak, AB'nin Türkiye ile kurduğu 
asimetrik ilişkinin OGSP açmazına yansıması ele alınmaktadır. Makalenin vardığı sonuç; NATO-AB-Türkiye üçgeninde yaşanan açmazın bir an önce çözülmesi gerektiği, ancak, yaşanan sorunların çözümü için sadece Türkiye'yi adres göstermenin doğru olmadığıdır. Bu bağlamda, AB'nin ve Birliğe üye ülkelerin yapması gereken çok şey vardır. Özellikle, AB üyesi olan NATO Müttefiklerine büyük sorumluluk düşmektedir. $\mathrm{Bu}$ ülkelerin, en başta, AB'ye karşı sorumluluklarını, NATO sorumluluklarının önünde tutmamaları gerekmektedir. NATO dayanışmasının da en az AB dayanışması kadar önemli olduğu aşikârdır. OGSP açmazı, Avrupa'da bazı çevrelerin öne sürdüğ şekilde sadece Türkiye'nin ayak diremesinden kaynaklanmamaktadır; dolayısıyla, çözüm de sadece Türkiye'den beklenemez.

\section{OGSP/AGSP Açmazının Arka Planı: Türkiye'nin BAB'a Ortak Üyelik Haklarını Kaybetmesi ve Endişeleri}

Soğuk Savaş'ın sona ermesi ile birlikte Batı Avrupa Birliği (BAB), Değiştirilmiş Brüksel Antlaşması'nın belirlediği ana işlevi dışında kendisine kriz yönetimi olarak belirlediği yeni bir görev tanımı yapmış ve üyelik yapısını da buna göre değiştirmiştir. Eskiden sadece tam üyeleri olan BAB, Ortak Üye (associate member), Gözlemci (observer) ve Ortak Partner (associate partner) statülerini de bünyesine katmıştır. Bu esnek üyelik yapısı ile BAB, Soğuk Savaş sonrasında ortaya çıkan yeni güvenlik ihtiyaçlarına Avrupa'daki tüm aktörleri içine alarak cevap vermeyi amaçlamıştır. Hatta bu kapsayıcı üyelik yapısına "BAB uluslar ailesi” (WEU Secretariat-General, Ocak 2000: 26) denilmiştir. İlgili ülkelerin, farklı üyelik şekilleriyle, değişen derecelerde BAB karar alma sürecine dâhil edilmeleri ve bu şekilde Avrupa güvenliğinde söz sahibi olmaları sağlanmıştır.

Türkiye, 1991 yılında, Maastricht Antlaşması'na eklenmiş bir deklarasyon (Deklarasyon No. 30) ile BAB'a Ortak Üye olarak davet edilmiştir. Ortak Üye statüsünün detayları BAB'ın 19 Haziran 1992 Petersberg Deklarasyonu ile belirlenmiş; İzlanda Cumhuriyeti, Norveç Krallığı ve Türkiye Cumhuriyeti'nin BAB Ortak Üyeliği Belgesi de, 20 Kasım 1992'de Roma'da kabul edilmiştir. Ortak Üyeler, NATO üyesi olan ancak AB üyesi olmayan devletlerdir. Fakat, NATO üyesi olmaları hasebiyle ${ }^{1} \mathrm{BAB}$ onlara neredeyse tam üyelerinin sahip olduğu haklar kadar hak tanımıştır. Bu bakımdan, Ortak Üyelerin, AB üyesi olup da NATO üyesi olmayan (Danimarka hariç) Gözlemciler ve her iki örgütün de üyesi olmayıp, sadece Sovyet Bloğundan bağımsızlı̆̆ını yeni kazanmış ve AB ile bir Avrupa Anlaşması imzalamış Orta ve Doğu Avrupa ülkelerinden oluşan Ortak Partnerlere kıyasla BAB'a çok daha fazla entegre olduklarını söylemek mümkündür.

\footnotetext{
${ }^{1}$ Bilindiği üzere, kurulduğu günden itibaren BAB ile NATO arasında organik bir bağ tesis edilmiştir. İki örgüt aynı asker ve kabiliyet havuzundan yararlandığı ve BAB tam üyeleri aynı zamanda NATO üyeleri oldukları için aralarında gizli bilgilerin paylaşımı konusunda herhangi bir problem de yaşanmamıştır. NATO üyesi olup da $\mathrm{AB}$ üyesi olmayan Avrupalı müttefiklerin BAB Ortak Üyeliği çerçevesinde daha avantajlı bir konuma sahip olmalarının nedeni de budur. Bu ülkeler, zaten NATO üyesi olduklarından, gizli bilgilerin paylaşımı gibi hassas konularda problem yaşamayacakları için karar alma mekanizmalarına daha yoğun bir şekilde dâhil edilmişlerdir.
} 
Ortak Üyeler, tam üyelerin Değiştirilmiş Brüksel Antlaşması (DBA) ile sahip oldukları hakların bazılarına doğal olarak sahip değillerdi. Çünkü onların statüsü DBA dışında kalan bir statüydü. ${ }^{2}$ Dolayısıyla, DBA'nın kolektif savunma garantisi içeren V. Maddesi, Ortak Üyeler için geçerli değildi. Ancak, Ortak Üyeler, BAB'ın Konsey toplantılarına, çalışma gruplarına ve yan kuruluşlarına katılabiliyorlardı. Ortak Üyeler, BAB'ın karar alma mekanizmalarına ise şu şartlar altında dâhil edilmişlerdi: Konsey toplantılarında konuşma, öneriler sunma ve oy kullanma hakları vardı. Ancak, BAB tam üyeleri tarafından oybirliği ile kabul edilmiş bir kararı veto etme hakları yoktu. Yani, katılımları DBA'nın VIII. Maddesi'ne aykırı olamazdı. ${ }^{3}$ Ortak Üyelerin karar alma sürecine katılımları ise ancak tam üyelerin basit çoğunluğu veya tam üyelerin Dönem Başkanlığını da kapsayan yarısının oyu ile mümkün olabiliyordu. Diğer bir deyişle, Ortak Üyelerin karar alma sürecine katılımını engellemek için tek bir tam üyenin vetosu yeterli değildi. Ayrıca, Ortak Üyeler, BAB Asamblesi'ne de katılabiliyorlard1.

Ortak Üyeler, aynı zamanda Planlama Hücresi'ne de dâhil edilmişlerdi. NATO'nun Bağımsız Avrupa Programı Grubu'nun devamı niteliğindeki Batı Avrupa Silahlanma Grubu'nun (WEAG) ise tam üyesiydiler. BAB operasyonlarına tam üyelerle eşit haklara sahip olarak katılıyorlardı ve BAB'a cevap verebilir kuvvetler kataloğuna katkıda bulunuyorlardı. BAB operasyonları hakkında bilgilendiriliyorlardı, her operasyon ile ilgili karar alma hakları vardı (yukarıda belirtilen koşullar çerçevesinde) ve ilgilendikleri operasyonlara katılabiliyorlardı. BAB operasyonlarına katılımları ile ilgili tek bir istisna vardı. O da, tam üyelerin basit çoğunluğunun bu yönde karar alması durumunda söz konusu olan operasyona katılmaları engellenebiliyordu. Öte yandan Ortak Üyeler, BAB tatbikatlarına da aynı statüde katılma hakkına sahiptiler.

Diğer DBA-dışı statülerden farklı olarak, Ortak Üyeler, BAB bütçesine katkıda da bulunuyorlardı. Elbette ki katkıları tam üyelerin katkılarından çok daha düşüktü. Ancak, BAB çerçevesinde haklarının dışında sembolik de olsa yükümlülüklerinin olması, onların diğer DBA-dışı üyeliklerden daha öncelikli ve avantajlı konumunun bir göstergesiydi. Daha önce de belirtildiği gibi, bu öncelikli durum, Ortak Üyelerin NATO üyesi olmasının doğal bir sonucuydu. Her ne kadar Amsterdam Antlaşması'nın Petersberg Görevlerini AB bünyesine katması ve bu görevlerin yerine getirilmesinde Birliğin BAB'1 (sanki bir alt kuruluşuymuş̧̧asına) görevlendirmesinin yolunu açması Ortak Üyeler ile Gözlemcilerin statüsünü birbirine yaklaştırmış olsa da; Ortak Üyeler, avantajlı statülerini Avrupa Güvenlik ve Savunma Politikası'nın oluşturulması ve BAB'ın feshedilmesi sürecine kadar korumuşlardır.

\footnotetext{
${ }^{2}$ Gözlemci ve Ortak Partner statüleri de DBA-dışı statülerdi.

${ }^{3}$ DBA'nın VIII. Maddesi, BAB'ın karar alma yöntemlerini şu şekilde belirlemiştir: oybirliği, üçte ikilik çoğunluk, basit çoğunluk. Buna göre, Ortak Üyelerin, tam üyelerin oy birliği ile kabul ettikleri bir kararı veto etmeleri mümkün değildi ama üçte ikilik çoğunluk ve basit çoğunluk ile alınan kararlarda oyları tam üyeler ile eşitti.
} 
Avrupa güvenliğinde gidişatı değiştiren en önemli gelişme Aralık 1998 St. Malo Zirvesi olmuştur. Bu zirvede Fransız ve İngiliz devlet ve hükümet başkanları, otonom bir Avrupa savunma kabiliyeti geliştirilmesi konusunda mutabık kalmışlardır. Bu kararın yolunu, İngiltere'nin yıllardır otonom bir Avrupa savunma gücünün geliştirilmesine karşı sürdürdüğü olumsuz tavrını bırakması açmıştır. St. Malo Zirvesinde alınan kararlar ABD ve NATO tarafından da kabul görmüştür. İlk tepkiyi, ABD, Madeleine Albright'1n ünlü 3D'sinden uzak durulması şartı ile vermiştir. ${ }^{4}$ Buna göre, otonom bir Avrupa savunma kabiliyeti geliştirilirken, Birliğin, NATO'nun imkân ve kabiliyetlerini kopyalanmasından, NATO içinde ABiçi veya $A B$ 'yi gözeten politik oyunlar oynanmasının yaratabileceği bir ayrışmadan ve $A B$ üyesi olmayan Avrupalı müttefiklerin herhangi bir ayrımcılığa uğramasından kaçınması istenmiştir (Albright, 7 Aralık 1998). NATO ise, Washington Zirvesi Bildirisinde ve aynı Zirvede kabul edilen Stratejik Konseptinde, geliştirilecek otonom Avrupa savunma kabiliyetinin, şu şartlar altında işlerlik kazanması durumunda kabul göreceğini açıklamıştır (North Atlantic Council, 24 Nisan 1999a ve 24 Nisan 1999b): AB sadece NATO’nun “tümüyle angaje olmadığı” yerlerde otonom operasyonlar düzenlemelidir. Diğer bir deyişle, kriz yönetiminde NATO her zaman için ilk merci olmalıdır. Ayrıca, NATO-AB ilişkileri ve AB ile AB üyesi olmayan Avrupalı Müttefiklerin ilişkileri, BAB çerçevesinde var olan düzenlemelerin üzerine inşa edilmelidir.

Haziran 1999'da toplanan Köln Avrupa Konseyi ${ }^{5}$ (European Council), Genel İşler Konseyi'ni Avrupa savunma kabiliyetinin oluşturulması konusunda görevlendirmiş ve bu bağlamda oluşturulacak kabiliyetin BAB'ın AB'nin Petersberg görevlerinin yerine getirilmesinde gerekli olan fonksiyonlarını üzerine alması için ihtiyaç duyulan düzenlemelerin yapılmasını istemiştir (Council of the European Union, 3-4 Haziran 1999). İlgili bildiride, gerekli düzenlemelerin 2000 yılı sonuna kadar gerçekleştirilmesi öngörülmüş ve bu durumda, BAB'ın artık bir örgüt olarak amacını tamamlamış olacağı ifade edilmiştir. Köln Bildirisi, BAB'ın lağvedilmesi ile ilgili süreci başlatması açısından önemlidir. Bu noktada, bir hususu belirtmekte fayda vardır: Her ne kadar BAB bir örgüt olarak 2000 yılı sonunda lağvedilmişse de DBA bir süre daha yürürlükte kalmış ve ancak 2010 yılı Mart ayında alınan bir kararla, 30 Haziran 2011 itibarı ile feshedilmiştir.

BAB'ın bir örgüt olarak lağvedilmesinin bir takım sonuçları olmuştur. Bunlardan en önemlisi, DBA-dışı statü ve görevlerin ortadan kalkmasıdır. Bu da Ortak Üye, Gözlemci ve Ortak Partner statülerinin artık var olmadığı anlamına gelmektedir. Tabii ki bu durum, ilgili statü sahiplerinin haklarının kaybolması sorununu doğurmuştur. NATO'nun Washington Zirvesi'nin öngördüğü şekilde $\mathrm{AB}$ üyesi olmayan Avrupalı müttefiklerin (BAB Ortak Üyelerinin) var olan BAB

\footnotetext{
4 Buradaki 3D; kopyalama, ayrışma ve ayrımcılık kelimelerinin İngilizcedeki karşılıkları olan duplication, decoupling ve discrimination terimlerinin baş harflerinden oluşmaktadır.

${ }^{5}$ AB üyelerinin Devlet ve Hükümet Başkanları seviyesinde temsil edildiği en üst karar alma merci (European Council). Bazı kaynaklarda, Türkiye'nin de üyesi olduğu Avrupa Konseyi (Council of Europe) ile karıştırılmaması için Avrupa Zirvesi olarak çevrilmektedir. Ancak, bu makalenin yazarı, Avrupa Konseyi terimini tercih etmektedir.
} 
mekanizmaları üzerine kurulacak bir sistem ile Ortak Avrupa Güvenlik ve Savunma Politikasına (OAGSP) dâhil edilmeleri konusu, Köln Avrupa Konseyi'nde ele alınmış, ancak Sonuç Bildirisi'nde bu durum son derece muğlâk bırakılmıştır. Aynı şekilde, Köln Bildirisi, NATO'nun kriz yönetimi konusunda ilk merci olduğuna dair herhangi bir ifadeye de yer vermemiştir. İlgili bildiri her iki konuda da genelde NATO, özelde ise AB üyesi olmayan Avrupalı Müttefikler tarafindan tatmin edici bulunmamıştır.

Aralık 1999 Helsinki Avrupa Konseyi, Sonuç Bildirisi'nde, bu problemleri düzeltmek yönünde Köln'e göre daha açık ifadelere yer vermiştir. Buna göre, $A B$, üyesi olmayan Avrupalı müttefiklerin kriz yönetimi aktivitelerine olabilecek en üst derecede katılabilmeleri için gerekli düzenlemelerin yapılacağını belirtmiştir. Ancak yine de bu ifadelerin içi tam olarak doldurulmamış ve Washington Zirvesi kararları ile tam bir uyum sağlanamamıştır. Sonuç Bildirisi’ne eklenen "Ortak Avrupa Güvenlik ve Savunma Politikası Hakkında İlerleme Raporu"nda, AB üyesi olmayan Avrupalı Müttefiklerin Birliğin kriz yönetimi operasyonlarına katılımı, NATO imkân ve kabiliyetlerinin kullanıldığı operasyonlar için kendi kararlarına; sadece- $A B^{6}$ operasyonları için ise Bakanlar Konseyi'nin davet edilmelerine yönelik kararına bırakılmıştır (Council of the European Union, 10-11 Aralık 1999a). Bu noktada, AB'nin OAGSP ile ilgili her konuda kararları oybirliği ile aldığının altı çizilmelidir. $\mathrm{Bu}$ açıdan balkıdığında, Helsinki bildirisi ile getirilen mekanizmanın, Washington Zirvesi'nin AB üyesi olmayan Avrupalı Müttefiklerin AGSP ile ilişkilerinin $\mathrm{BAB}$ çerçevesinde var olan düzenlemelerin üzerine inşa edilmesi ilkesine aykırı olduğu söylenebilir. Hatırlanacağı üzere, Ortak Üyelerin herhangi bir BAB operasyonuna katılımı ancak tam üyelerin basit çoğunluğu ile engellenebilmekteydi. Oysa Helsinki ile getirilen mekanizmaya ve OAGSP kararlarının oybirliği ile alınması ilkesine göre, AB üyesi olmayan Avrupalı Müttefiklerin sadece- $A B$ operasyonlarına katılımını engellemek tek bir AB üyesinin vetosu ile mümkün olabilmektedir. Öte yandan $A B$ üyesi olmayan Avrupalı müttefiklerin katılımı ile gerçekleştirilen bir operasyon durumunda ise, harekâtın başladığı andan itibaren kurulacak olan Katılımcılar Komitesinde tüm katılımcıların eşit oyu olacak ve sahada harekâtın gündelik yönetiminden bu komite sorumlu tutulacaktı. Ancak, bir operasyonun siyasi kontrolü ve stratejik yönlendirmesi her zaman Siyaset ve Güvenlik Komitesi tarafindan yapılacaktı.

Helsinki Sonuç Bildirisi, NATO’nun ilk merci olduğunu kabul etmiş ve geliştirilecek olan Avrupa Acil Müdahale Gücü'nün Avrupa ordusu anlamına gelmediğini vurgulamıştır (Council of the European Union, 10-11 Aralık 1999b). Avrupa Acil Müdahale Gücü'nün geliştirilmesine yönelik olarak ise Avrupa Konseyi, Helsinki Temel Hedef'ini belirlemiştir. Buna göre, AB'ye üye devletlerin, 2003 yılına kadar, altmış günde konuşlandırılabilecek ve bir yıl sürdürülebilecek 50.000-60.000 kişilik kuvvetler oluşturmaları zorunlu kılınmıştır (Council of the European Union, 10-11 Aralık 1999b). Feira Avrupa Konseyi ise, aynı şekilde, AB

6 "Sadece-AB operasyonu" terimi, yalnızca AB kabiliyetleriyle, NATO imkân ve kabiliyetleri kullanılmadan yapılan operasyonlar anlamına gelmektedir. 
üye devletlerinin oluşturmasını öngördüğü sivil kriz yönetimi kabiliyetlerini şöyle belirlemiştir: 2003'e kadar 5000 polisten oluşan bir kriz yönetimi kuvveti oluşturulması ve 30 güne kadar 1000 kişilik bir polis gücünün konuşlandırılabilmesi (Council of the European Union, 19-20 Haziran 2000). Nice Avrupa Konseyi, bir yandan AGSP'nin ${ }^{7}$ yürütülmesine ilişkin kurumları belirlemiş ${ }^{8}$, diğer yandan da AB üyesi olmayan Avrupalı Müttefiklerin AGSP mekanizmalarına katılımı ile ilgili olarak Helsinki'de geliştirilen düzenlemeleri tekrar etmiştir. (Council of the European Union, 7-9 Aralık 2000). Bu arada, ne Helsinki ne de Nice Avrupa Konseyleri, AB üyesi olmayan Avrupalı müttefiklerin AGSP tatbikatlarına katılımı ile ilgili herhangi bir prosedür öngörmemişti. $\mathrm{Bu}$ da, mevcut durumun korunması halinde, ortak tatbikat eksikliğinin, $\mathrm{AB}$ üyesi olmayan Avrupalı müttefiklerin $\mathrm{AB}$ kuvvetleriyle birlikte çalışabilirliklerini azalmasına yol açabileceği anlamına gelmekteydi.

Türkiye'nin, o dönemde, genelde AGSP'ye katılımı ve özelde Helsinki ve Nice kararları ile ilgili sorunları şöyle özetlenebilir: Öncelikle, Türkiye'nin kaybetmiş olduğu BAB Ortak Üyelik hakları yeterince telafi edilmemişti. Bu da NATO'nun Washington Zirvesi kararlarının $\mathrm{AB}$ üyesi devletler tarafından düzgün bir şekilde uygulanmadığının göstergesiydi. ${ }^{9}$ Türkiye'nin bu şekilde BAB Ortak Üyelik haklarından yoksun bırakılması aynı zamanda onun Avrupa güvenliğinde oynadığı "rolün azalması" (Cem, 29 Mayıs 2001) anlamına da gelmekteydi. Soğuk Savaş boyunca NATO'nun güney kanadında Avrupa güvenliğine önemli katkılar sağlamış olan ve kendini askeri gücü ile tanımlayan bir ülke için bu durum olumsuz bir psikolojik bir etki de yaratmaktaydı.

Öte yandan, Türkiye, kendisine coğrafi yakınlığı bulunan ve/veya önemli ulusal çıkarlarını etkileyecek bir bölgede yapılacak AB operasyonları için önceden kendisine bilgi verilmesini ve danışılmasını istiyordu. NATO'nun belirlemiş olduğu ana kriz alanlarından birçoğunun Türkiye'nin etrafında olduğu düşünüldüğünde, bu bölgelere yapılacak olası bir AB harekâtının ülke için bazı olumsuz sonuçlar doğurması kaçınılmaz olabilirdi ve bu noktada, Türkiye, Birliğin kendisini haberdar etmesini ve ilgili operasyonlar konusunda görüşlerinin kayda alınmasını, yani aslında sesini duyurmay1, istiyordu (Öymen, 2001: 404).

Türkiye, ayrıca, AGSP'nin kendisine karşı kullanılmasından endişe etmekteydi. Nice Avrupa Konseyi öncesi Kıbrıslı Rumların adadaki Birleşmiş Milletler Barış Gücü'nün yerine ileride Avrupa Acil Müdahale Gücünün konuşlandırılabileceğini

\footnotetext{
${ }^{7}$ Bu noktada, AGSP'nin ismi ile ilgili olarak bir açıklama yapmak gerekmektedir. Köln Avrupa Konseyi ile birlikte bu politika, ilk ortaya çıktığı andan itibaren, OAGSP adıyla anılmaya başlamıştır. Ancak, zamanla hem OAGSP hem de AGSP terimleri kullanılmış, Nice Avrupa Konseyi ile AGSP, resmi dokümanlarda, OAGSP'nin yerini almaya başlamış ve Aralık 2002 Kopenhag Avrupa Konseyi'nden itibaren ise sadece AGSP terimi kullanılır olmuştur. Bilindiği üzere, Lizbon Antlaşması'nın öngördüğ̈̈ şekilde artık sadece Ortak Güvenlik ve Savunma Politikası (OGSP) terimi kullanılmaktadır.

${ }^{8}$ Siyaset ve Güvenlik Komitesi, Askeri Personel, Askeri Komite. Council of the European Union (7-9 Aralık 2000).

${ }^{9}$ Çünkü Washington Zirvesi, NATO-AB ilişkileriyle ve NATO'nun AB üyesi olmayan Avrupalı Müttefikleri ile ilgili düzenlemelerin, BAB'da geliştirilmiş olan düzenlemeler üzerine kurulması gerektiğini açıkça belirtmişti.
} 
açıklaması Türkiye'nin bu endişesini doğrular nitelikteydi (Missiroli, 2002: 17). Diğer taraftan, daha önce de belirtildiği gibi, sadece- $A B$ operasyonlarına katılımın Bakanlar Konseyi kararı ve davetiye ile olması, tek bir AB üyesinin vetosunun Türkiye'yi sürecin dışında bırakılması anlamına geliyordu. Yunanistan dışında, 2004 yılında üye olması kesinleşen Güney Kıbrıs'ın da bu vetoyu işletmesi söz konusu olabilirdi. En kötü senaryo göz önüne alındığında ise, şöyle bir durum da olasıydı: NATO'nun müdahale gerektiren herhangi bir kriz durumunda ilk merci olması kuralına uyulduğu ve NATO'nun da oybirliği ile karar aldığı düşünülürse, tek bir NATO üyesinin (örnek: Yunanistan) ilgili duruma müdahaleyi veto etmesi mümkündü. Böyle bir olasılıkta, duruma müdahale kararı AB'ye kalmış olacaktı. AB'de de kararların oybirliği ile alındığg düşünüldüğünde, yine tek bir ülkenin (örnek: Yunanistan), önce ilgili operasyonun NATO imkân ve kabiliyetlerinin kullanılarak yapılmasına karşı çıkması ve sadece- $A B$ kabiliyetleri ile yapılmasını sağlaması, sonra da Türkiye'nin bu operasyona katılımını veto etmesi teknik ve teorik olarak mümkündü. Bu tip bir en kötü senaryo, özellikle Türkiye'ye coğrafi yakınlığı bulunan bir bölgeye veya ülkenin ulusal çıkarlarını etkileyecek bir yere $\mathrm{AB}$ müdahalesi olması durumunda ülke için ciddi bir sorun teşkil edebilirdi.

Türkiye, tüm bu endişelerinin sonucunda, AB'nin NATO'dan istediği imkân ve kabiliyetlerin otomatik olarak verilmesine karşı çıkmış, durum bazında değerlendirme ve her seferinde Kuzey Atlantik Konseyi onayı istemiştir. Türkiye, ayrıca, AB'nin NATO'nun Washington kararları üzerine kurulacak yeni düzenlemeler yapmasını ve özellikle coğrafi olarak kendisine yakın olan veya ulusal çıkarlarını ciddi şekilde etkileyecek bölgelere müdahale konusunda, Birliğin öncelikle kendisine danışmasını talep etmiştir. Ankara, ayrıca, beraber çalışabilirlik ile ilgili olarak ileride bir sıkıntı yaşanmaması için AB tatbikatlarına katılım da istemiştir (Öymen, 2001: 404). Türkiye, bu talepleri yerine getirilinceye kadar, AB'nin NATO imkân ve kabiliyetlerini kullanmasını bloke etmiştir. Hatta bu sebeple bazı Avrupalı araştırmacılar tarafından esnek olmamak ve siyaseten sorunlu olmakla itham edilmiştir. ${ }^{10}$

\section{Ankara Mutabakatı (İstanbul Belgesi) ${ }^{11}$ ve Berlin Artı Düzenlemeleri}

Ankara'nın talepleri yankı bulmakta gecikmemiş, İngiltere ve ABD Aralık 2001'de Türkiye'ye bir öneri paketi sunmuşlardır. Bu öneri öncelikle, AB üyesi Müttefiklerin NATO'ya karşı sorumluluklarına saygılı davranacaklarını teyit ediyordu. Ayrıca, hiçbir kriz durumunda, AGSP bir Müttefike karşı kullanılmayacaktı. Paket, ayrıca, AB üyesi olmayan Müttefikler ile Birlik arasında daha sıklaştırılmış danışma mekanizmaları içeriyordu. $\mathrm{Bu}$ da ilgili Müttefiklerin

\footnotetext{
${ }^{10}$ Örnek: Missiroli (2002: 19) ve Grant (10 Eylül 2001: 2).

${ }^{11}$ Ankara Mutabakatı birçok kaynakta Ankara Anlaşması olarak geçmektedir. Bu makalenin yazarı, Türkiye'nin AB ile Ortaklık Anlaşması da aynı ismi taşıdığından, iki belge karıştırılmasın diye Ankara Mutabakatı terimini kullanmayı tercih etmektedir. Öte yandan, belgenin resmi ismi, İstanbul Belgesi'dir. Çünkü, belge üzerindeki mutabakata İstanbul'da varılmıştır. Ancak, Ankara'nın üzerinde anlaştığı son belge olması hasebiyle belgeye Ankara Mutabakatı denmiştir (Missiroli, 2002: 21). İstanbul Belgesi, içeriği açıklanmamış bir belgedir. Bu paragrafta sunulan bilgiler aşağıdaki kaynaklardan derlenmiştir: Missiroli (2002: 21-22), Boulton ve Dempsey (4 Aralık 2001) ve Sarribrahimoğlu (4 Aralık 2001).
} 
daha fazla seslerini duyurabilmeleri ve AGSP ile daha ileri seviyede ilişkilendirilmeleri anlamını taşıyordu. Bu bağlamda, ilgili müttefikler Siyaset ve Güvenlik Komitesi ile daimi temas halinde bulunabileceklerdi. Aynı zamanda Askeri Komite'ye askeri temsilci atayabileceklerdi. Coğrafi yakınlık kriterine uygun olarak, AB üyesi olmayan Avrupalı Müttefiklerin yakınındaki bölgelerde bir kriz olması durumunda - özellikle bu kriz ilgili ülkelerin ulusal çıkarlarını ciddi bir şekilde etkileme potansiyeline sahipse - o zaman, AB Konseyi bu ülkelerle diyalog ve danışma mekanizmalarını çalıştıracaktı. Tüm bunlar karşılığında, Türkiye NATO'nun planlama ile ilgili belirli imkân ve kabiliyetlerine AB'nin garantili erişiminin önünü açacaktı; stratejik imkân ve kabiliyetler için ise durum bazında değerlendirme yapılacaktı (Aykan, 2005: 347-348). ${ }^{12}$ İstanbul Belgesi Türkiye tarafından bu şartlarla kabul edilmiştir. Ancak, yaklaşan yerel seçimlerin de etkisi ile bu sefer Yunanistan Belgeyi reddetmiştir. ${ }^{13} \mathrm{Bu}$ da İstanbul Belgesi'ni ölü bir belge haline getirmiştir. Ancak bu Belge, sonrasında geliştirilecek olan çözümün temelini oluşturduğu için, çok önemli bir belgedir.

Yunanistan'ın anlaşmak için öne sürmüş olduğu şartlar ise şöyle sıralanabilir ${ }^{14}$ :

- NATO ve AB'nin eşit örgütler olduklarının ve karar alma otonomilerinin tanınmasi.

- Bazı endişelerin giderilmesine yönelik olarak karşılıklılık ilkesi gözetilmesi; yani eğer AGSP bir NATO ülkesine karşı kullanılamayacaksa, bir NATO ülkesinin de bir AB ülkesine karşı kuvvet kullanmaması.

- $\mathrm{Bu}$ bağlamda, ilişkilerde kuvvet kullanımı ve kuvvet kullanımı tehdidinin önüne geçilmesi.

- NATO ve AB ülkeleri arasındaki anlaşmazlıkların barışçıl yollarla çözümlenmesi.

Berlin Art ${ }^{15}$ düzenlemeleri Yunanistan ve Türkiye'nin endişe ve prensipleri göz önüne alınarak ve aylarca üzerinde düşünülüp pazarlıklar yapılarak hazırlanmış belgelerden oluşmaktadır. Bu düzenlemelerin kabulü ile ilgili ilk adım 24-25 Ekim

\footnotetext{
${ }^{12}$ İstanbul Belgesi'nden önce İngilizler tarafından Ankara'ya sunulan bir başka öneriden de bu noktada bahsetmek gerekir. Çünkü bu öneri, AB'nin garantili erişiminin sağlanacağı NATO imkân ve kabiliyetleri arasında bir "stratejik" ve "stratejik olmayan" ayrımına gidilmesini öngören ilk girişimdir. $\mathrm{Bu}$ ayrım bilindiği üzere Berlin Artı düzenlemelerinin de önemli bir unsurunu oluşturmuştur. Türkiye'nin bu düzenlemeleri kabul etmesindeki etmenlerden birinin de bu ayrım olduğu söylenebilir. Bu öneri ile ilgili olarak bkz.: Dempsey (30 Mayıs 2001).

${ }^{13}$ Yunanistan'in vetosu ile ilgili olarak bkz.: Dempsey (11 Aralık 2001).

${ }^{14} \mathrm{Bu}$ sıralama, o dönemde Yunan Dışişleri Bakanı olan Papandreou'nun Turkish Daily News'a yaptığı açıklamalardan derlenmiştir. "Papandreou briefs the TDN over the basic principles for the EU army: Both Ankara and Athens open for discussions over the ESDP" (27 Haziran 2002).

15 "Berlin Artı" terimindeki "Berlin" ifadesi, NATO'nun Haziran 1996 Berlin Konsey toplantısında alınan; Avrupalı Müttefiklerin, İttifakın tümüyle katılmadı̆̆ı operasyonlarda NATO imkân ve kabiliyetlerini (Birleşik Müşterek Görev Kuvvetleri kapsamında) kullanabilmesine yönelik yöntemleri belirleyen kararlarına atfen kullanılmaktadır. Buradaki "artı" ifadesi ise, yeni geliştirilen düzenlemelerin, temelde, NATO’nun 1996 yılında Berlin Konsey toplantısında alınan kararların üzerine kurulduğunu anlatmak için kullanılmaktadır.
} 
2002 tarihlerinde Brüksel'de düzenlenen Avrupa Konseyi toplantısında atılmıştır. Türkiye'nin Yunanistan'ın da öne sürdüğü ilkeleri göz ardı etmeyen bir plan üzerinde anlaşabileceğini bildirmesiyle, Brüksel Avrupa Konseyi, AB üyesi olmayan Avrupalı Müttefiklerin AGSP'ye katılımına dair modaliteleri Sonuç Bildirisi'ne eklenmiş olan ve analizciler tarafından "Nice Uygulama Belgesi" olarak anılan belge ile belirlemiştir (Council of the European Union, 26 Kasım 2002). Bu belgenin en ilgi çeken yanı, giriş bölümünde ilk olarak $A B$ üyesi Müttefiklerin, NATO sorumluluklarına saygılı olacaklarını (Avrupa Birliği Antlaşması'nda belirtildiği şekilde) tekrar etmeleridir (Council of the European Union, 26 Kasım 2002). ${ }^{16}$ Bunun hemen akabinde ise, AGSP'nin hiçbir şart altında bir Müttefike karşı kullanılmayacağı garanti altına alınmıştır.

Belge ayrıca, AB üyesi olmayan Avrupalı müttefiklerle danışma ve görüşme mekanizmalarını çeşitli formüllerle arttırmıştır. İlgili Müttefiklerin önemli ulusal çıkarları öne sürmeleri durumunda, ek bir takım danışma mekanizmaları da öngörülmüştür. Ayrıca, bu ülkelerin, günlük iletişimi sağlamak üzere Siyaset ve Güvenlik Komitesi ile Askeri Komiteye temsilciler atamaları karara bağlanmıştır. $\mathrm{AB}$ üyesi olmayan Avrupalı müttefiklerin $\mathrm{AB}$ operasyonlarına katılımı ise, Helsinki ve Nice'te öngörülen düzenlemelerle aynı şekilde bırakılmıştır. ${ }^{17}$ İlgili müttefiklerin $\mathrm{AB}$ tatbikatlarına katılımı konusunda da aynı prosedür işleyecektir. Operasyon durumunda, harekâtın günlük idaresinden Katılımcılar Komitesi sorumlu tutulmuşsa da operasyonun genel siyasi kontrolü ve stratejik yönlendirmesi yine Siyaset ve Güvenlik Komitesi'ne bırakılmıştır. Bu da göstermektedir ki, gerek barış zamanlarında gerekse operasyon durumunda, AB üyesi olmayan Avrupalı Müttefiklerin AGSP'ye katılımı sadece karar şekillendirme ile sınırlandırılmış, bu ülkelerin karar almaya dâhil edilmeleri söz konusu olmamıştır.

Brüksel Avrupa Konseyi'nde alınan kararlar NATO ve AB Genel Sekreterleri arasında Aralık 2002'de bir mektup teatisi yapılmasının yolunu açmıştır. ${ }^{18} 12-13$ Aralık 2002 Kopenhag Avrupa Konseyi'nde konu ile ilgili varılan kapsaml anlaşma memnuniyet ile karşılanmış ve Makedonya'ya yapılacak askeri operasyon için AB'nin artık hazır olduğu açıklanmıştır (Council of the European Union, 29 Ocak 2003). Avrupa Konseyi, aynı zamanda, ek bir Bildiri kabul etmiştir. Bu bildiri ile Kıbrıs ve Malta'nın Berlin Artı düzenlemelerine dair konumları belirlenmiștir. Buna göre: Berlin Artı düzenlemeleri sadece ya NATO üyesi olan ya da Barış İçin Ortaklık'a katılan ${ }^{19}$ AB üyeleri için geçerli olacaktı. Kıbrıs ve Malta'nın 2004 yılında üye olmaları halinde de bu değişmeyecekti. Ancak, bu durumun iki ülkenin AB'nin Ortak Dış ve Güvenlik Politikasına ve AGSP'nin Berlin Artı düzenlemeleri

\footnotetext{
${ }^{16}$ Avrupa Birliği Antlaşması, Madde 17(1).

17 Sadece- $A B$ operasyonlarına Avrupa Birliği Konseyi davetiyesi esastır. NATO'nun imkân ve kabiliyetlerinin kullanıldığı operasyonlara katılım ise AB üyesi olmayan Avrupalı Müttefiklerin kendilerinin isteğine bağlıdır.

${ }^{18}$ Bu mektuplardan Lord Robertson'a ait olan, halka açık bir belge olmakla beraber, Solana'nın mektubu gizlidir. Bu da aslında her zaman şeffaflığı ve açıklığı ilke olarak ileri süren bir uluslararası kuruluş olan $\mathrm{AB}$ için oldukça ilginç ve üzerinde durulması gereken bir durumdur.

19 Malta'nın Berlin Artı konusunda bir anlaşmaya varılması için katılımcısı olduğu Barış için Ortaklık'tan çekilmiş olması da unutulmaması gereken bir husustur.
} 
dışında kalan kısımlarına katılımlarını engellemeyeceği Bildiride özellikle vurgulanmıştı. Aynı şekilde, bu ülkelerin, AB'nin gizli bilgilerine ulaşımı da - bu belgeler NATO gizli bilgileri içermediği sürece - engellenmeyecekti.

Berlin Artı düzenlemeleri konusunda geliştirilen çözüm, 16 Aralık 2002 tarihli AGSP ile ilgili AB-NATO Deklarasyonu'nda da dile getirilmiştir (NATO, 16 Aralık 2002). Bu Deklarasyon, iki örgüt arasındaki ilişkileri etkili karşılıklı danışma, diyalog, işbirliği, şeffaflık, eşitlik, her iki örgütün de karar alma otonomisine ve çıkarlarına saygı, üyeler arasındaki anlaşmazlıkların barışçıl yollarla çözümü ve ilişkilerde kuvvet kullanımı veya kuvvet kullanımı tehdidinin kullanılmaması ilkeleri temeline oturtmuştur. NATO'nun kriz yönetiminde ilk merci rolü bir kez daha tekrarlanmış, AB'nin NATO'nun planlama kabiliyetlerine erişimi garanti altına alınmıştır. AB üyesi olmayan Avrupalı Müttefiklerin AGSP'ye katılımlarının ise Solana'nın mektubunda belirlenen usullere göre sağlanacağı belirtilmiştir. Solana'nın mektubu gizli olduğundan içeriği bilinmemekle beraber, mektubun bu konu ile ilgili olarak Ekim 2002 Brüksel Avrupa Konseyi sonuçlarına eklenen Nice Uygulama Belgesinde yer alan usulleri tekrar ettiği tahmin edilmektedir. Berlin Artı düzenlemeleri, son olarak 17 Mart 2003 tarihinde kabul edilmiş olan bir dizi gizli belge ile tamamlanmıştır.

\section{Berlin Artı Sonrası Gelişmeler ve AGSP Açmazı}

Berlin Artı düzenlemelerinden, 2004 yılında Kıbrıs'ın AB üyesi olmasına kadar geçen süre içersinde, Birlik, ilk kriz yönetimi operasyonlarını gerçekleştirmiştir. 31 Mart 2003'te Makedonya'da başlayan Concordia operasyonu yalnızca AB'nin ilk harekâtı değil aynı zamanda Berlin Artı düzenlemelerinin işletildiği ilk kriz yönetimi görevidir. Üstelik başarılı bir operasyon olduğu düşünülmektedir. Operasyon Aralık 2003 'te sona ermiş, Türkiye de bu operasyona katkı sağlamıştır. Bosna'da 2 Aralık 2004 tarihinde başlatılan ve NATO İstikrar Gücü'nün yerini alan Althea operasyonu da aynı şekilde Berlin Artı düzenlemelerinin kullanıldığı bir harekât olmuştur. Althea, AB'nin en büyük askeri operasyonudur ve Türkiye de bu operasyona $\mathrm{AB}$ dışından en büyük katkıyı sağlayan devlettir. Ayrıca katkı sağlayan tüm devletler arasında da ikinci sıradadır. Althea halen devam etmektedir. Berlin Artı düzenlemeleri ile yapılan her iki harekâtın da başarılı olması AB'nin kriz yönetimi konusunda deneyim kazanmasında önemli rol oynamış ve $\mathrm{AB}$ daha sonra birçok sadece- $A B$ askeri operasyonuna girişmiş ve sivil kriz yönetimi görevleri üstlenmiştir. Türkiye de bu operasyonlardan bazılarına farklı düzeylerde katkı sağlamıştır.

Kıbrıs'ın AB üyeliği ile birlikte AGSP açmazı tekrar ortaya çıkmıştır. Kopenhag Avrupa Konseyi Sonuç Bildirisi'nde Kıbrıs ve Malta'nın konumu açıkça belirtilmiş olmasına rağmen, AB bu konuda NATO ve Türkiye'ye verdiği sözleri tutmamış ve her iki ülkenin de artık Birliğe tam üye olmaları hasebiyle NATO-AB işbirliğinin dışında bırakılamayacaklarını öne sürmüştür (Ülgen, 2008: 2). Bunu yaparken AB'nin iddiası, bu ülkelerin artık tam üye olmalarının otomatikman Birliğin dayanışma ilkesinin uygulanmasını gerektirdiğidir. Elbette, bu noktada, 2002 yılında Berlin Artı düzenlemeleri ile ilgili sözleri verirken AB'nin Kıbrıs ve 
Malta'nın üye olacağını ve bu ilkeyi işletmek durumunda kalabileceğini bildiğini belirtmekte fayda vardır. Bu da şu soruyu akla getirmektedir: AB tutamayacağını bildiği bu sözleri neden vermiştir? Hoffmann ve Reynolds bir NATO yetkilisine dayandırarak bu soruya başka bir soruyla cevap vermektedir. Onlara göre Berlin Artı düzenlemelerinin getirdiği çözüm acaba NATO-AB ilişkilerinin "sadece belli bir dönemine yönelik bir çözüm müdür?" (Hoffmann ve Reynolds, Haziran 2007: 2) Varwick ve Koops'a göre ise zaten AB'nin asıl amacı, NATO-AB işbirliğini geliştirmekten çok kendi otonom savunma kabiliyetlerini geliştirmek için ilk etapta Berlin Artı düzenlemeleri yoluyla NATO'nun deneyiminden yaralanmaktır (Varwick ve Koops, 2009: 102). Varwick ve Koops'un açıklamaları 1şı̆̆ında, Hoffmann ve Reynolds'ın cevabını bilerek sordukları soru daha da anlam kazanmaktadır.

Birliğin NATO-AB işbirliği çerçevesinde yapılacak toplantılara Güney Kıbrıs'ın da katılımı konusundaki ısrarına karşılık, Türkiye Rum Yönetimi'nin katılımını bloke etmiştir. Bunun en önemli sebebi Kıbrıs ile resmi bir toplantıda aynı masada oturmasının o ülkeyi tanımak anlamına gelecek olmasıdır. Türkiye, ayrıca, Güney Kıbrıs'ın NATO ile güvenlik anlaşması imzalamasını da veto etmektedir. Buna karşılık olarak, Kıbrıs da Türkiye'nin AB ile güvenlik anlaşması imzalamasını engellemekte ve Türkiye'nin Avrupa Savunma Ajansı'na çeşitli düzenlemelerle dâhil edilmesini de veto etmektedir. Bazı analizciler Türkiye ile Kıbrıs'ın karşılıklı vetolarla sitemi bloke etmesine "çifte veto" adını vermektedirler (Hoffmann ve Reynolds, Haziran 2007: 7). ${ }^{20}$

Öte yandan, Türkiye'nin Avrupa Savunma Ajansı'na katılımının engellenmesi önemli bir hak kaybına yol açmaktadır. Unutulmamalıdır ki, Türkiye Avrupa Savunma Ajansı'nın selefi olan WEAG'ın tam üyesiydi. ${ }^{21}$ Yani, bu açıdan da, Türkiye için bir hak kaybı söz konusu olmuştur.

Kıbrıs, ayrıca, kendisinin ve Malta'nın ${ }^{22}$ olmadığı platformlarda mevcut Berlin Artı operasyonları dışında herhangi bir konunun müzakere edilmesini de bloke etmektedir. Bu sebeple, AB ve NATO arasında Althea operasyonu dışında hiçbir konu görüşülememektedir. Öte yandan, Türkiye NATO-AB işbirliğinin tamamen bloke olmaması ve önemli meselelerin görüşülebilmesi için Kıbrıs ve Malta'nın da katıldığı resmi olmayan toplantılar yapılmasına razı olmuştur. Bu şekilde yapılan birkaç toplantının ardından ise, bu sefer Fransa, önemli konuların resmi olmayan ortamlarda konuşulmasının doğru olmayacağı gerekçesi ile süreci bloke etmiştir (Hoffmann ve Reynolds, Haziran 2007: 4 ve Koenig, 2010: 14). Bu da AGSP açmazının önemli bir boyutu olan NATO'daki Avrupacı ayrışmayı göstermektedir. Çünkü Fransa'nın buradaki amacı, Türkiye-Kıbrıs çekişmesine bir şekilde müdahil olmaktan çok, AB-NATO ilişkilerini sekteye uğratmak ve bu vesileyle, AB'nin kriz

\footnotetext{
${ }^{20}$ NATO-AB-Türkiye ilişkilerindeki açmaz ile ilgili olarak Kıbrıs'ın önemini ön plana çıkaran bir çalışma için, bkz. Akgül Açıkmeşe ve Triantaphyllou (2012).

${ }^{21}$ Üstelik WEAG da, bir NATO kuruluşu olan Bağımsız Avrupa Program Grubu'nun (IEPG) devamıydı.

${ }^{22}$ Her ne kadar Malta da karşılıklı veto blokajından nasibini almışsa da, 2008 yılında Barış için Ortaklık'a geri dönerek kendini sarmalın dışına atmayı başarmıştır. Howorth (2009: 97, dipnot 5).
} 
yönetiminde birincil aktör olarak öne çıkmasını sağlamaktır (Hoffmann ve Reynolds, Haziran 2007: 4). Fransa'ya göre, NATO'nun rolü sadece kolektif savunma ile sinırlandırılmalıdır (Hoffmann ve Reynolds, Haziran 2007: 4).

\section{NATO-AB İlişkilerindeki Sorunlar ve NATO’daki Avrupacı Ayrışma}

NATO-AB ilişkilerindeki bazı sorunlar AGSP açmazının da temelini oluşturmaktadır. Hoffmann ve Reynolds, bu sorunları şöyle sıralamaktadır: Berlin Artı anlaşmalarının AB-NATO ilişkilerindeki kapsayıcılığının farklı yorumlanması (ki bu farklı yorumlara anlaşmaların muğlak bırakılmış olması da sebebiyet vermektedir); NATO'nun kriz yönetimi operasyon ve misyonlarında ilk merci (ilk reddetme yetkisine sahip merci) olup olmadığına dair farklı anlayışlar; ve görev dağılımı ile ilgili olarak her iki örgütün de farklı amaçlarının olması (Hoffmann ve Reynolds, Haziran 2007: 2). ${ }^{23}$

Berlin Artı düzenlemelerinin AB-NATO ilişkilerindeki kapsayıcılığının farklı yorumlanması konusu özellikle sivil kriz yönetimi alanında kendini göstermiştir. $\mathrm{AB}$, Irak ve Gürcistan'a yapılan operasyonlarını Türkiye'ye haber vermeden gerçekleştirmiştir. Yani, Berlin Artı mekanizmaları gereğince Türkiye'yi coğrafi olarak kendisine yakın bölgelerde düzenlenecek ve ulusal çıkarlarını etkileyebilecek operasyonlar konusunda bilgilendirmek ve danışma mekanizmalarını işletmek yükümlülüğünü bu operasyonlarda yerine getirmemiştir. Birlik, buna gerekçe olarak, ilgili harekâtların, sivil kriz yönetimi operasyonları olmalarını ileri sürmüştür. AB'nin yorumuna göre, bu tip operasyonlar Berlin Artı düzenlemelerinin kapsamına girmemektedir, çünkü Berlin Artı düzenlemeleri sadece askeri harekâtlar için geliştirilmiştir (Buharalı, 2010: 7). Birliğin bu düzenlemeleri mümkün olduğunca dar kapsamlı olarak yorumlamaya çalıştığını söylemek mümkündür. Öte yandan, başını Türkiye'nin çektiği Transatlantikçi NATO üyeleri, bu düzenlemelerin kapsamını, tüm kriz yönetimi faaliyetlerini içerecek şekilde yorumlamaktadır.

NATO'nun kriz yönetimi operasyon ve misyonlarında ilk merci olup olmadığına dair farklı anlayışlar da değişik vesilelerle ortaya çıkmıştır. Haziran 2003'te başlatılan Artemis Operasyonu bu anlamda bir ilk teşkil etmiştir. Çünkü bu operasyon gerçekleştirilmeden önce ne ABD ne de NATO ile bir danışma mekanizması çalıştırılmamıştır. Bu şekilde AB, NATO'nun ilk merci olması ilkesini göz ardı ederek, kendi otonom askeri kriz yönetimi operasyonunu gerçekleştirmiştir. Diğer taraftan, bir başka örnekte, Darfur'da, NATO ve AB müşterek bir operasyon gerçekleştirme konusunda birbirleriyle anlaşamamış ve aynı bölgede iki farklı harekâta girişmişlerdir. Bu hem NATO'nun ilk merci olması ilkesini anlamsız kılan bir örnektir hem de her iki örgüt içindeki Avrupacı ve Transatlantikçi kampların iyice ortaya çıkması açısından önemlidir. Darfur konusunda, Fransa, Almanya ve Yunanistan sadece- $A B$ operasyonu

\footnotetext{
${ }^{23}$ Hoffman ve Reynolds kendi makalelerinde bu sorunları sadece sıralamış ancak açıklamalarını detaylı bir şekilde yapmamışlardır. Oysa bu sorunlar üzerinden yapılacak örneklemeler AGSP açmazının ve NATO'daki Avrupacı ayrışmanın çok daha iyi bir şekilde açıklanmasını sağlayabilir. Bu makalenin yazarı aşağıda geliştirilen örneklemeyi kendisi yapmıştır.
} 
gerçekleştirilmesini savunmuşlar; İngiltere, Hollanda ve İtalya ise NATO operasyonundan yana olmuşlardır. Bazı analizcilere göre, Darfur konusundaki çekişme, NATO ile AB arasındaki rekabetin ve alan kavgalarının da boyutunu gözler önüne sermiştir. ${ }^{24}$

NATO ve AB arasındaki görev dağılımı ile ilgili olarak, iki örgütün farklı amaçlarının olması açısından da sorun yaşanmaktadır. AB sivil kriz yönetiminde geliştirmiş olduğu kabiliyetleri ile bu alanda önde gelen bir aktör olmayı amaçlamaktadır. Öte yandan NATO ise, son Stratejik Konseptinde de belirlediği gibi, kriz yönetimi konusunda krizin her safhasını (öncesi, sırası ve sonrası) içeren, kapsamlı politik, sivil ve askeri araçların tümünün etkili ve etkin kullanımını öngörmektedir. $\mathrm{Bu}$ bağlamda, çeşitli platformlarda, AB'nin İttifakın sivil kabiliyetlerini geliştirmesi için bir tür "Tersine Berlin Artı" düzenlemesi yoluyla NATO'ya destek sağlayıp sağlayamayacağı konusu tartışmaya açılmıştır. ${ }^{25}$ Ancak, özellikle Avrupacı AB üyelerinin, NATO'nun AB'nin sivil imkân ve kabiliyetlerinden yararlanacağı bu tip bir mekanizmanın hayata geçirilmesine karşı çıktıkları görülmüştür. Özellikle Fransa'nın başını çektiği bu ülkeler, NATO'nun ileride kendi sivil kabiliyetlerini geliştirerek AB'ye rakip olmasından endişe etmektedirler (Varwick ve Koops, 2009: 118-119).

$\mathrm{Bu}$ da aslında, Avrupacı Müttefiklerin, bir yandan otonom bir Avrupa kriz yönetimi ve savunma kabiliyeti geliştirilmesini isterken, öte yandan NATO'ya nasıl zarar verdiklerinin önemli bir göstergesidir. Bu noktada, NATO içindeki Avrupacı ayrışma problemini detaylarıyla ele almakta fayda vardır. Bilindiği üzere, Transatlantik ilişkilerdeki eğilimlerine ve Avrupa güvenliğine yaklaşımlarına göre değerlendirildiklerinde, $\mathrm{AB}$ içinde iki grup üye devlet olduğundan bahsetmek mümkündür: Liderliğini Fransa'nın yaptığı Avrupacı grup ve İngiltere'nin başı çektiği Transatlantikçi grup. Avrupacı grubun en önemli özelliği, ABD'nin Avrupa'daki askeri varlığına şüpheci yaklaşmaları ve bu bağlamda Avrupa'nın kendi otonom savunma kabiliyetlerini geliştirmesi taraftarı olmalarıdır. Bu grubun günümüzdeki amacı, NATO'nun rolünü kolektif savunma ile sınırlı tutmak, AB'nin ise kendi bağımsız askeri ve sivil kriz yönetimi kabiliyetlerini mümkün olduğunca geliştirmesini ve etkili bir aktörlük sergilemesini sağlamaktır. Transatlantikçi grup ise, ABD'nin Avrupa'daki askeri varlığına sicak bakmakta, NATO'nun Avrupa güvenliğindeki birincil konumunu korumaya çalışmakta ve İttifak' in sadece kolektif savunma örgütü değil, aynı zamanda askeri kriz yönetimi için de ilk merci olduğunu vurgulamaktadır. Onlara göre, AB, NATO'nun aleyhine bir durum yaratacak, İttifak'ın imkân ve kabiliyetlerinin gereksiz yere kopyalanmasına yol açacak ve iki örgüt arasında rekabet yaratacak herhangi bir girişimden kaçınmalıdır. ${ }^{26}$

\footnotetext{
${ }^{24}$ Örnek: Cascone (2008: 157); Varwick ve Koops (2009: 112).

25 "Tersine Berlin Artı" modeli ile ilgili olarak bkz.: Kammel ve Zyla (2011: 648-662).

${ }^{26}$ Avrupa güvenliğine yaklaşımları açısından bu iki gruba da dâhil olmayan ancak onlar arasında bir denge tutturmaya çalışan başka $\mathrm{AB}$ ülkeleri de vardır. İsveç ve Finlandiya gibi tarafsızlar bu ülkeler arasında sayılabilir. Öte yandan, en katı Transatlantikçi ülke olan Danimarka ise OGSP'ye katılmamaktadır.
} 
$\mathrm{Bu}$ makalede Avrupacı ayrışma olarak tanımlanan durum, Fransa'nın başını çektiği bu grubun AB'deki siyasi oyunlarını NATO'ya taşımaları/yansıtmaları ve İttifak içindeki duruş ve tavırlarını NATO'nun değil, AB'nin çıkarlarına göre belirlemeleridir. Avrupacı Müttefikler çoğu zaman otonom bir Avrupa savunma kabiliyeti geliştirilmesine yönelik çabalarını NATO içinden ve İttifak'ın zararına işleyecek ve NATO-AB işbirliğini mayınlayacak politikalarla sürdürmektedirler.

Fransa'nın bu konudaki tavrı ile ilgili şu örnek çok önemlidir ${ }^{27}: 2006$ yılında üye devletler, NATO ve AB irtibat takımlarını, aktiviteleri ile ilgili olarak müşterek bir döküm raporu hazırlama konusunda görevlendirmişlerdir. Her iki tarafın da raporu siyasi müdahalelerle içerikten yoksun bir halde ortaya çıkmıştır. Ancak bu noktada ilginç olan, Ocak 2007'de NATO'da sunumu yapılan raporun AB'ye gönderilmesinin Fransa tarafindan veto edilmesidir. Çünkü, bunun hemen ertesi gününde, aynı raporun $\mathrm{AB}$ versiyonu için Birlik içinde yapılan görüşmelerde, raporun NATO'ya gönderilmesi yine Fransa tarafindan veto edilmiştir. Fransa'nın bu veto için gerekçesi ise daha da ilginçtir: NATO'nun kendi raporunu AB'ye göndermeyi reddetmesi ve dolayısı ile AB'nin de aynı oranda karşılık vermesi gerektiği. Görüldügü üzere, Fransa, bilerek ve isteyerek, NATO-AB ilişkilerini sabote etmektedir. 2009 yılında Fransa'nın NATO'nun Entegre Askeri Komutası'na geri dönmesinin amacının da bu çerçevede değerlendirilmesi mümkündür. Fransa'nın asıl amacının, NATO'ya daha fazla müdahil olmaktan çok, İttifakın içinde tam kontrol sağlamak ve bu şekilde Avrupa savunma kabiliyetlerinin otonomlaştırılmasını daha kolay ve çabuk başarmak olduğu söylenebilir. ${ }^{28}$

Fransa'nın çok benzer bir tavrı, çifte veto yüzünden bloke olan NATO-AB ilişkilerini resmi olmayan görüşmelerle açma çabalarına karşı göstermekte olduğunu hatırlamakta fayda vardır. Bilindiği üzere, Fransız temsilciler, güvenlik ve savunma gibi çok önemli konuların gayrı resmi toplantılarda ele alınamayacağ savını öne sürerek bu çabaları bloke etmektedir (Hoffmann ve Reynolds, Haziran 2007: 4). Dolayısı ile AGSP/OGSP açmazının ve NATO-AB ilişkilerindeki tıkanmanın sadece Türkiye ve Kıbrıs'ın çifte vetosu yüzünden ortaya çıktığını savunmak doğru değildir. Açmaza etki eden, çok daha tarihi ve derin izler taşıyan başka bir dinamik daha vardır. Bu da, görüldüğü üzere NATO-AB ilişkilerindeki Avrupacı ayrışmadır. Çifte veto ise, Avrupacı ayrışmanın amaçlarına ister istemez hizmet etmektedir.

Fransa'nın başını çektiği ülkelerin, Concordia ve Althea gibi NATO imkân ve kabiliyetleri ile gerçekleştirilmiş operasyonları, AB'nin kendi otonom kriz yönetimi gücünü geliştirmesi için deneyim kazandığ birer vesile olarak gördüğü ve NATO$\mathrm{AB}$ işbirliğine de sadece bu amaçla ve bir süreliğine olumlu yaklaştıkları söylenebilir (Varwick ve Koops, 2009: 102). Bu da Avrupacı Müttefiklerin

\footnotetext{
${ }^{27}$ Burada verilen örnek Hoffmann ve Reynolds'da anlatılanların bir özetidir (Hoffmann ve Reynolds, Haziran 2007: 5).

${ }^{28}$ Lachman, yaptığı bir mülakatta, ilgili Avrupalı yetkilinin Fransa’nın NATO-AB ilişkileri ve kriz yönetimi bağlamında, $\mathrm{AB}$ konusunda "fazla korumacı" olduğunu söylediğini belirtmektedir (Lachman, 2010: 29).
} 
NATO’yu sadece AB'nin uluslararası kimliğini ve görünürlüğünü arttırmakta bir atlama taşı olarak değerlendirdikleri anlamına gelmektedir (Varwick ve Koops, 2009: 125). İlgili ülkelerin NATO'dan bağımsız bir Avrupa savunma kabiliyeti geliştirmek üzere ilk girişimleri, Nisan 2003'te, Irak savaşının yarattığı Transatlantik bölünme döneminde olmuştur. Fransa, Almanya, Belçika ve Lüksemburg düzenledikleri bir zirve toplantısıyla sadece-AB operasyonlarının komutası için Belçika Tervuren'de otonom bir Avrupa Karargâhı kurulmasını önermişlerdir. "Praline Zirvesi" veya "Tervuren Vakası" olarak da adlandırılan bu zirvede alınan kararlar, kurulacak bu tip bir karargâhın NATO imkân ve kabiliyetlerinin gereksiz yere kopyalanması anlamına geleceğini düşünen $\mathrm{ABD}$ ve Transatlantikçi AB üyeleri tarafından tepki ile karşılanmıştır. Kasım 2003'te, İngiltere aracılığıyla, bu konuda her iki tarafi da memnun edecek bir anlaşmaya varılması sağlanmıştır. Bu anlaşmaya göre, Belçika'nın Mons kentindeki NATO karargâhı SHAPE'in içinde bir Avrupa Planlama Hücresi ve AB Askeri Personeli'nde bir sivil-askeri hücre kurulmuştur. Bu sivil-askeri hücre 2004'te bir AB Operasyon Merkezi kurulması ile görevlendirilmiştir ve bu Merkez 2007 yılında göreve başlamıştır.

Praline Zirvesi, NATO içindeki ayrışmaya ve Avrupacı Müttefiklerin AB'nin çıkarlarını nasıl kendi NATO sorumluluklarının önünde tuttuğuna dair somut bir örnek olmuştur. Zirvenin, özellikle Transatlantik ilişkilerin Irak savaşı yüzünden krize girdiği ciddi bir döneme denk gelmiş olması, bu ülkelerin NATO'yu zayıf düşürecek her türlü firsatı değerlendirdiklerinin de bir göstergesidir. Öte yandan bazı Avrupalı analizciler, asıl ABD'nin Irak savaşında takınmış olduğu tutumun ve bu konuda İttifak üzerinden gitmek yerine Müttefikleri ile ikili ilişkiler üzerinden işbirliği geliştirmesinin NATO'da bir ABD ayrışmasına yol açtığını iddia etmektedirler. ${ }^{29} \mathrm{Bu}$ eleştirilerin de doğru olduğunu ve ABD'nin bu tutumunun, NATO'nun rol ve durumunu sorgulanır hale getirdiğini söylemek mümkündür. ${ }^{30}$

Yine 2003 Irak savaşı ile ilgili olarak bir başka Avrupacı ayrışma örneği, savaş öncesinde Amerika'nın müdahalesi sırasında kendisinin Irak'ın saldırısına uğrayabileceğinden endişelenen Türkiye'nin, ABD'nin telkinleriyle, NATO Antlaşmasının V. Maddesinin işletilmesine yönelik olarak yapmış olduğu çağrının, Almanya, Fransa ve Belçika tarafından reddedilmesidir. Bu ülkeler her ne kadar NATO'nun rolünün kolektif savunma ile sınırlı kalmasını arzu ettiklerini belirtseler de, bu örnek, onların aslında zamanı geldiğinde NATO'nun kolektif savunma garantisinin de işletilmesine karşı çıktıklarını göstermiştir. Bu da, NATO’nun, V. Madde ile ilgili olarak, hem güvenilirliğini hem de caydırıcılığını yitirmesi anlamına gelmektedir. ${ }^{31}$ Nitekim, 1991 Irak müdahalesi sırasında da benzer bir durumun yaşanmış olduğu göz önüne alındığında, Türkiye'nin 2003 Irak örneğinden sonra NATO Antlaşmasının V. Maddesine güvenmesi çok zorlaşmış ve tüm acil durum planlarını ona göre yapması gerektiği de açıkça ortaya çıkmıştır.

\footnotetext{
${ }^{29}$ Örnek: Duke (2008: 36).

${ }^{30}$ Ancak, bu makalenin öne sürdüğ̈̈ argüman bakımından NATO içindeki Avrupacı ayrışmaya burada daha çok yer verilmiş, ABD ayrışmasının detaylarına girilmemiştir.

${ }^{31}$ NATO'nun V. Maddesi ve uygulanışı konusundaki sıkıntılar ile ilgili olarak bkz.: Fedyszyn, (2010).
} 
$\mathrm{Bu}$ örnek, aynı zamanda, $\mathrm{AB}$ içindeki dayanışma ilkesini öne sürerek NATO-AB işbirliğine Kıbrıs'ın dâhil edilmesi konusunda 1srarcı olan Avrupalı Müttefiklerin, NATO dayanışması söz konusu olduğunda nasıl sessiz kaldıklarını da göstermesi bakımından önemlidir.

NATO'nun savunma garantisi konusunda en önemli gelişme ise 2012 yılı sonunda olmuştur. Suriye'deki iç savaşın kendi topraklarını ve vatandaşlarını tehdit eder bir hal alması üzerine Türkiye, hava savunmasının desteklenmesi için, 21 Kasım 2012 tarihinde NATO Antlaşmasının IV. Maddesinin işletilmesine dair bir çağrı yapmıştır. 4-5 Aralık 2012 tarihli NATO Dışişleri Bakanları toplantısında Müttefikler Türkiye'nin bu çağrısına olumlu yanıt vermişlerdir. Bu çerçevede Almanya, Hollanda ve ABD Türkiye'ye Patriot füzelerinin konuşlandırılması sürecini başlatmışlardır. Ancak, özellikle Almanya ve Hollanda tarafından konuşlandırılacak olan füzelerin niteliği göz önüne alındığında, sağlanan desteğin, pratikte yaratacağ1 etkiden çok sembolik önem taşıdığ1 söylenebilir. Türkiye'nin bu yöndeki isteğinin üçüncü kez reddedilmiş olsayd1, bu kuşkusuz NATO Antlaşmasının V. Maddesinin güvenilirliği konusunda ciddi bir tahribat yaratırdı. Müttefiklerin, ilgili kararı alırken bu konuyu dikkate almış olmaları kuvvetle muhtemeldir. Ancak, başka durumlarda Türkiye'nin NATO'ya ve özellikle Avrupalı Müttefiklere güvenip güvenemeyeceği sorusu hala çok net cevaplanamamaktadır. NATO içindeki Avrupacı ayrışma devam ettiği sürece bu soruyu yanıtlamak çok zor olacaktır.

Öte yandan, Avrupacı ayrıșma, kendini Avrupa Savunma Ajansı konusunda da göstermiştir. Berlin Artı düzenlemeleri, NATO-AB arasında kabiliyetlerin geliştirilmesi konusunda da işbirliği öngörmekteydi. Hatta buna yönelik olarak bir NATO-AB Kabiliyet Grubu da kurulmuştu. Ancak 2004 yılında Avrupa Savunma Ajansı'nın kurulması ile birlikte, bazı Avrupacı AB üyeleri, Berlin Artı düzenlemelerinin bu alanda getirdiklerini tartışmaya açmışlardır (Cascone, 2008: 153). Avrupa Savunma Ajansı'na katılımı konusunda Türkiye'nin hak kaybı da göz önüne alındığında, Avrupacı müttefiklerin, AB'nin çıkarlarını NATO sorumluluklarının önüne koyarken, aynı zamanda, OGSP açmazını besledikleri söylenebilir. Öte yandan, bu açmazda, Avrupacı ayrışma kadar, AB'nin Türkiye ile ilişkisini sadece adaylık hattı üzerine oturtmuş olmasının da etkisi vardır ve bu konu da irdelenmelidir.

\section{OGSP Açmazında AB-Türkiye İlişkilerinin Rolü}

$\mathrm{AB}$, aday ülkelerle ve kendi refahından pay almak isteyen üçüncü ülkelerle ${ }^{32}$ kurallarını - çoğunlukla, derecesini/hızını da - kendisinin belirlediği ve söz konusu ülkelerin uymak zorunda kaldığ bir ilişki biçimi geliştirmiştir. $\mathrm{Bu}$, yukardan aşağıya, asimetrik bir ilişkidir: $\mathrm{AB}$ kuralları koyar, uygulanması için şartlar öne sürer ve muhatabı olan ülkeler de bu kuralları kabul edip şartları yerine getirmek durumunda kalırlar. Bu tip yukarıdan aşağıya bir yaklaşım, her ne kadar birçok

${ }^{32}$ Avrupa-Akdeniz İşbirliği ülkeleri gibi. 
analizci tarafından ${ }^{33}$ normatif - demokrasi, insan hakları ve hukukun üstünlüğü gibi değerlerin geliştirilmesinde olumlu - bir ilişki olarak anlatılmaya çalışılsa da, çoğunlukla üçüncü ülkelerin AB'den sadece bir takım ekonomik faydalar sağlayabilmek için belirli değerleri içselleştirmeden ve araçlaştırarak kullandıkları bir ortam yaratmıştır. Bunda AB'nin bu ülkelerde istediği reformların/uygulamaların ne şekilde yapılacağına, o ülkedeki sosyoekonomik ve kültürel yapıyı ve daha da önemlisi, "yerel-yerellerin"34 ihtiyaçlarını göz önüne almadan, çoğu zaman tek taraflı olarak karar vermesinin ciddi etkisi vardır. $\mathrm{Bu}$ ilişki biçimi, üçüncü ülkelerin $\mathrm{AB}$ ile işbirliklerinin "müşterek sahibi" 35 olamamasına, yani bu işbirliğini kendilerininmişçesine benimseyememesine ve dolayısı ile içselleştirememesine neden olmaktadır. AB, kurduğu bu ilişkilerde muhatabını sürekli olarak söz konusu işbirliğinin karar-alma sürecinin dışında birakmaktadır. $^{36}$

AB'nin bu asimetrik tutumunun Adaylar ile ilişkilerinde tamamen ön planda olduğunu söylemek mümkündür. Zaten Birliğe katılım müzakerelerinin temel prensibi de budur. Öte yandan, aday ülkelerin durumu kabul etmesinin nedeni ise Heather Grabbe'ye göre açıktır, çünkü bu ülkeler AB karşısında, asimetrik bağımlılıktan kaynaklanan zayıf bir pozisyondadırlar (Grabbe, 2006: 1): "Onlar, üyeliği, var olan üye ülkelerin onları kabul etmeyi istediğinden çok daha fazla istemişlerdir. Aslında, Birliğin genişleme konusundaki kendi kararsızlığı onun

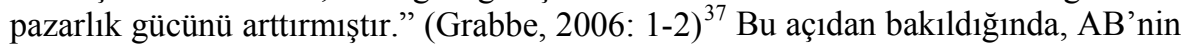
tüm aday ülkelerle aynı ilişki biçimini benimsemiş olduğu ve aslında bu ülkelerle başka bir ilişki biçimi geliştirmenin yollarını da pek bilmediği veya bunu istemediği söylenebilir. Her şeyden önce bu asimetrik tutum AB'nin ve üye devletlerinin çıkarlarına tam hizmet etmektedir.

Birliğin NATO-AB işbirliği çerçevesinde Türkiye'ye yaklaşımı da bu kendi lehine asimetrik ilişki geliştirme alışkanlığ zaten tam da bu sebeple ortaya çıkmaktadır. Çünkü NATO-AB ilişkilerinde, başından beri ricacı konumda olan taraf AB olmuştur: Birlik AGSP alanında aldığı kararların uygulanabilmesi için NATO imkân ve kabiliyetlerine garantili erişim istemiştir. Bu erişimin sağlanıp sağlanmayacağı ile ilgili kararı alacak olan merci ise karar alma otonomisi $\mathrm{AB}$ tarafından da çeşitli resmi belgelerde defalarca tanınmış olan NATO'dur. İttifak, kararlarını oybirliği ile almaktadır ve Türkiye de NATO'nun tam üyesidir. Yani bu durumda Türkiye'nin AB'nin erişim isteğini veto etme hakkı vardır ve AB burada Türkiye'den ricacı konumdadır. Oysa AB, Türkiye

\footnotetext{
${ }^{33}$ Örnek: Manners (2002).

${ }^{34}$ Yerel-yereller tanımı burada ilgili ülkelerde AB'nin çoğunlukla kendisinin kurduğu ve desteklediği sivil toplum dışında kalan halkı anlatmak için kullanılmaktadır. Yerel-yereller (local-locals) tanımı için bkz. Richmond (2009: 566).

${ }^{35}$ Avrupa-Akdeniz İşbirliği sürecinde müşterek sahiplik ile ilgili yaşanan problemler için bkz. Del Sarto ve Schumacher (2005: 29).

${ }^{36} \mathrm{Bu}$ noktada, AB'nin Ortaklık Konseyleri gibi mekanizmalarla bu ülkelere karar almada söz hakkı verdiği eleştirisi gelebilir. Ancak, bu Konseylerin yapıları, işlevleri ve toplantı içerikleri de yine AB tarafindan belirlenmektedir.

${ }^{37}$ Burada Grabbe'nin “onlar” dediği, Orta ve Doğu Avrupa ülkeleridir.
} 
ile geliştirmiş olduğu ilişki şeklinde (adaylık süreci) Türkiye'nin ricacı konumda olmasına alışık olduğundan, bu durumu idrak edememiş ve Türkiye'nin vetosu karşısında nasıl davranması gerektiğini akılcı bir yolla belirleyememiştir. Bunun yerine, birçok Avrupalı analizcinin öne sürdügü şekilde Türkiye'nin uzlaşmaz, esneklikten ve politik nezaketten uzak davrandığı argümanının ardına sığınmıştır. ${ }^{38}$

$\mathrm{AB}$, bir yandan Türkiye'nin kendi otonom karar-alma mekanizmalarına haksız yere müdahale etmeye çalıştığını öne sürmüş, diğer yandan NATO'nun otonom bir örgüt olduğunu göz ardı etmiştir. ${ }^{39}$ Birlik, üyelerinin başka örgüt çatıları altındaki savunma yükümlülüklerine halel getirilmemesine dair kendi antlaşmalarında yer alan açık hükümlere rağmen, NATO'nun Washington Zirvesi kararlarının hiçbirini tam olarak benimsememiş ve uygulanmaları konusunda son derece isteksiz davranmıştır. ${ }^{40}$ Bunun da ötesinde, önceleri NATO’nun kriz yönetiminde ilk merci olması ilkesini bile göz ardı etmeye çalışmış, ancak gelen tepkiler üzerine Helsinki Avrupa Konseyi Sonuç Bildirisi'nde bu ilkeye yer vermek zorunda kalmıştır. Buna rağmen, yukarıda da belirtildiği üzere, Avrupacı üyeler bu ilkeye hala karşı çıkmakta ve ilkenin erozyona uğratılması için çaba göstermektedirler. Berlin Artı düzenlemelerinden bir buçuk yıl sonra ise, Kıbrıs'ın tam üyeliği üzerine, $A B$, bu düzenlemeler çerçevesinde verdiği taahhütlerden hiçbirini yerine getirmemeye başlamıştır. Çifte vetoların da devreye girmesi ve Avrupacı Müttefiklerin bu durumdan fazlasıyla yaralanmasıyla da NATO-AB işbirliği süreci tamamen bloke olmuştur.

\section{OGSP Açmazıyla Yaşamak: Bir Değerlendirme}

Hemen hemen her AB resmi belgesi - Lizbon Antlaşması da dâhil olmak üzere - AGSP/OGSP ile ilgili olarak, bu politikanın üye devletlerin başka yapılar içindeki savunma sorumluluklarına halel getirmeyeceğini vurgulamaktadır. Lizbon Antlaşması'nın bu bakımdan önemi, NATO'nun ismini açıkça telaffuz etmiş olmasıdır. Antlaşmaya göre ${ }^{41}$, OGSP alanındaki sorumluluklar ve işbirliği, NATO sorumluluklarıyla tutarlı olmalıdır ve üyesi olan devletler için İttifak, onların kolektif savunmasının temelini oluşturmaktadır. ${ }^{42}$ Lizbon Antlaşmasına eklenmiş olan Daimi Yapılandırılmış İşbirliği Protokolü de, ilgili üye devletlerin Kabiliyet

\footnotetext{
${ }^{38}$ Bkz. Grant (10 Eylül 2001) ve Missiroli (2002: 19).

${ }^{39}$ Koenig (2010: 11), bir NATO yetkilisinin bir mülakatta kendisine NATO-AB arasındaki rekabet için, şunları söylediğini belirtmektedir: "AB, bütünleşmeci bir proje çerçevesinde kurulmuş olduğu için kendisini her zaman daha üstün bir örgüt olarak görür. NATO'da sadece koordinasyon vardır ve bütünleşme yoktur. AB bürokrasisindeki bası kişiler, NATO'nun eşit ağırlığa sahip olabileceği fikrini kabul etmezler. [...] AB kendisini gelecek olarak görür, oysa NATO çoğunlukla geçmiş olarak görülür."

${ }^{40} \mathrm{Bu}$ isteksizliğin en önemli göstergelerinden biri Berlin Artı düzenlemeleri çerçevesinde Türkiye'nin her sene AGSP için tahsis ettiği ve AB'nin Yetenek Taahhüdü Kataloğunda yer alan kuvvetlerinin, 2007 yılında, aynı kataloğun "Ekler” kısmına konulması olmuştur. Türkiye, bunun üzerine, AGSP'ye yapmış olduğu askeri katkıyı askıya almış, ancak İtalya ve Romanya ile birlikte 2010 yılının ikinci yarısında oluşturacağ1 Muharabe Grubu'na yapacağı katkının süreceğini bildirmiştir. Bkz. "Türkiye, AB'ye Askeri Desteğini Geri Çekti” (7 Haziran 2007).

${ }^{41}$ Madde 28A(7).

${ }^{42}$ Lizbon Antlaşması, geleneksel V. Madde kolektif savunma hükmünden daha esnek de olsa, silahlı saldırıya uğrayan üyelerinin yardımına gidilmesi bağlamında bir karşılıklı savunma hükmü içerdiği için, bu vurgu önem kazanmaktadır.
} 
Geliştirme Mekanizmasını iyileştirmek için, NATO'da geliştirilmiş düzenlemelere halel getirmeyecek şekilde çalışmalarını öngörmüştür. NATO da Stratejik Konseptinde (NATO, Kasım 2010) daha güçlü ve yetkin bir Avrupa savunması geliştirilmesinin önemine dikkat çekmiş ve bu çerçevede Lizbon Antlaşması ile getirilen yeni düzenlemeleri memnuniyetle karşıladığını bildirmiştir. Aynı zamanda, AB üyesi olmayan Avrupalı Müttefiklerin Birliğin çabalarına yaptığı katkıları vurgulamış; onların tam katılımının ve NATO-AB stratejik ortaklığının esas teşkil ettiğinin altını çizmiştir. NATO ile AB'nin birbirini tamamlayan ve destekleyen rollere sahip olması gerekliliği de bir kez daha belirtilmiştir.

Her ne kadar resmi belgeler NATO-AB ilişkilerinin ana hatlarını net bir şekilde çizmiş olsalar da, uygulamanın onların çizdiği resme hiç uymadığını söylemek mümkündür. $\mathrm{AB}$ üyesi ülkeler NATO-AB ilişkileri genelinde ve $\mathrm{AB}$ üyesi olmayan Avrupalı Müttefiklerin OGSP'ye katılımı özelinde hem Birlik hem de İttifak içinde vermiş oldukları sözlerin hiçbirini tutmamışlardır. Bunun en önemli nedeni, bu ülkelerin NATO'yu - aynı Amsterdam Antlaşması sonrası BAB'ı içine soktukları Birliğin bir alt pozisyonu gibi ${ }^{43}$ - bir araç olarak görmeleridir. Bu, özellikle Avrupacı AB üyelerinin açıkça benimsemekte beis görmedikleri bir tavırdır. ${ }^{44} \mathrm{Bu}$ açıdan bakıldığında, NATO'daki Avrupacı ayrışma probleminin NATO-AB ilişkilerine ve özellikle de AGSP/OGSP açmazına çok ciddi bir etkisi olduğu sonucuna varmak mümkündür.

NATO Genel Sekreteri Rasmussen'in 2010 yılında NATO-AB işbirliği ve OGSP açmazını çözmek için yaptığı öneri ve girişimler Berlin Artı düzenlemeleri ile AB'nin zaten kabul etmiş olduğu, ancak, 1srarla uymadığ 1 hükümlerin uygulanması isteğinden öteye geçememiştir. Rasmussen, açıkladığı iki rotalı inisiyatifle AB-Türkiye güvenlik anlaşmasının ve Türkiye'nin Avrupa Savunma Ajansı'na katılımını sağlayacak düzenlemeler ile ilgili idari anlaşmaların imzalanmasını, bunun karşılığında da NATO'nun Kıbrıs'ın iki örgüt arasındaki görüşmelere teknik düzeyde katılmasına izin vermesini önermiştir (Symanski ve Terlikowski, 17 Kasım 2010: 2). Yani, Rasmussen, Berlin Artı düzenlemelerinden geri bir adımla, AB'nin vermiş olduğu sözler uyarınca zaten çoktan yapmış olması gereken bu uygulamaları gerçekleştirmesi karşılığında, Türkiye'den Kıbrıs konusunda taviz vermesini istemiştir. Bu öneriler, aslında, AB'nin verdiği sözlerin hiçbirini tutmamasının NATO için çok da problem teşkil etmediği gibi bir görüntü de ortaya çıkarmakta ve $\mathrm{AB}$ üyelerinin OGSP açmazı konusunda tek sorunun Türkiye'nin uzlaşmaz tavrı olduğu savına hizmet etmektedir. $\mathrm{Bu}$ da sorunun çözümsüzlügünü devam ettirmektedir. Oysa bu makalede gösterilmeye çalışıldığ

\footnotetext{
43 Amsterdam Antlaşması, BAB'ın Petersberg görevlerini, AB'nin kriz yönetimi görevleri haline getirmiş ve bu görevlerin uygulanması için AB'nin BAB'1 "kullanacağını/görevlendireceğini” ("The Union will avail itself of the WEU") belirtmiştir. Madde J.7(3). Burada kullanılan terim "to avail oneself of" Maastricht Antlaşması'nda AB'nin Ortak Dış ve Güvenlik Politikası'nın savunma sonuçları olan kararlarının uygulanmasını BAB'dan isteyeceğine dair kullanılan "The Union requests the Western European Union" ibaresinden [Madde J.4(2)] farklıdır. Amsterdam Antlaşması'ndaki bu ifade birçok analizci tarafindan BAB'ın AB'ye göre ikincil bir konuma sokulduğu (onun alt bir kurumuymuşçasına) yorumlanmıştır. Örnek: Ortega (1998: 1-13).
}

${ }^{44}$ Bkz. dipnot 39, supra. 
üzere sorun sadece Türkiye'den kaynaklanmamaktadır ve çözümü de yalnızca bu ülkeden beklenemez.

Güney Kıbrıs'ın Temmuz-Aralık 2012 AB Konseyi Dönem Başkanlığı da NATO-AB ilişkileri açısından ayrı bir durağanlık sebebi olmuştur. Temmuz 2012 'den itibaren altı ay boyunca Türkiye'nin, tanımadığı bir ülkenin başkanlığını yaptığ 1 bir örgütle nasıl ilişki kuracağı başlı başına bir problem olarak görülmüştür. Hatta bir süre, Althea'ya askeri, EUPM Bosna ve EULEX Kosovo'ya sivil alanda katkı yapan Türkiye'nin Kıbrıs'ın bu operasyonların komutasında söz sahibi olması olasılığı karşısında bu harekâtlara katkısını geri çekip çekmeyeceği bile tartışılmıştır (Gürer, 27 Aralık 2011). Türkiye bu süre boyunca Kıbrıs'ın Başkanlık ettiği toplantılara katılmamış ve AB'nin diğer uluslararası örgütler çerçevesindeki bildirilerine iştirak etmemiştir (European Commission, 10 Ekim 2012). Kıbrıs'ın Dönem Başkanlığı, çok büyük sorunlar yaşanmasa da gergin ve durağan şekilde tamamlanmıştır.

NATO'nun Libya müdahalesi, Avrupa devletlerinin savunma kabiliyetleri konusunda çok önemli bir takım gerçekleri açığa çıkarmıştır. Öncelikle, Avrupalı ülkeler, $\mathrm{AB}$ yerine NATO üzerinden hareket etmeyi tercih etmişlerdir. Alessandri'ye göre bu durum, AB'nin halen "kendi başına, tekil ve yaşayabilir bir güvenlik aktörü olmaktan uzak olduğunun" göstergesidir (Alessandri, 2012: 27). Avrupa'nın en büyük iki devleti ve askeri gücü Fransa ve İngiltere'nin başını çektiği Avrupalı müttefiklerin kabiliyetleri Libya'nın havadan bombalanmasına bile yetmemiştir ve bu devletler sonunda ABD'den destek istemek durumunda kalmışlardır. ${ }^{45}$ Hatta Avrupalı Müttefiklerin bu güçsüzlüğü ve savunma harcamalarındaki düşüş üzerine NATO Genel Sekreteri Rasmussen bu sorunlara dikkat çeken bir makale kaleme almak durumunda kalmıştır (Rasmussen, Temmuz/Ağustos 2011). Seidler ise, AB üyesi devletlerin bu ve benzeri yetersizliklerini göz önüne alarak, prestij kaygılarını bir tarafa bırakıp, OGSP'yi feshetmelerini ve bunun yerine NATO'ya konsantre olarak, savunma harcamalarını İttifaka yöneltmelerini önermiştir (Seidler, 3 Kasım 2011). Kuşkusuz ki Seidler'in önerisi biraz abartılıdır. Ancak, gerçekten de, bu küresel finansal kriz, istikrarsızlık ve tahmin edilemezlik ortamında Avrupalı Müttefiklerin yapması gereken; eski ve kısır politik oyunlar oynama zihniyetini bir kenara bırakmak ve etkin bir NATO$\mathrm{AB}$ işbirliği geliştirmektir. Bunun da en önemli boyutu OGSP açmazını hep birlikte çözmektir. Fransa'nın başını çektiği Avrupacı ülkelerin öncelikle anlamaları gereken budur.

\section{Sonuç}

Dünya artık eskisi gibi, Batılı ülkelerin yeni-kolonyal mantık ve politikalarla kolayca yönettiği bir alan değildir. Güç, hızla ve doğuya doğru el değiştirmektedir. Kuzey Afrika ve Orta Doğu ülkelerinde yaşanan dönüşümün AB'nin "normatif" 46

\footnotetext{
${ }^{45}$ Bkz. Joyner (25 Ağustos 2011).

${ }^{46}$ Örnek: Manners (2002).
} 
ve "medenileştirici" 47 etkisi ile değil de, bambaşka sebeplerden meydana geldiği aşikârdır. Dolayısıyla üçüncü ülkeler de artık AB'ye karşı, onun alıştığı şekilde, güçsüz durumda değildirler. AB'nin üçüncü ülkelerle ilişkilerini daha eşitlikçi ve müşterek sahiplenmeye dayalı bir temele oturması şarttır. Türkiye'nin OGSP'ye dâhil edilmesi ve NATO-AB işbirliğindeki blokajını kaldırması konusunda da AB'nin daha eşitlikçi, verdiği sözleri tutmak üzerine kurulu ve kendi hatalarından ders alan yeni bir tutum geliştirmesi şarttır. Bu noktada, Türkiye'nin de kendisini sürekli haksızlığa uğrayan ve üyesi olduğu NATO içinde bile dışlanmaya çalışıldığını devamlı tekrar eden bir ülke konumundan çıkartması ve yenilikçi, yapıcı ve yaratıcı çözüm önerileriyle elini daha da kuvvetlendirmesi gerekmektedir. Bu bağlamda, Suriye krizi konusunda NATO’nun IV. Maddesinin işletilmesiyle, Türkiye'nin hava savunmasının Müttefikleri tarafından desteklenmesi sembolik de olsa, önemli bir adımdır.

Bu makale, Türkiye'nin OGSP açmazından sorumlu tutulacak tek faktör/aktör olmadığını ve sorunun başka boyutları olduğunu göstermeye çalışmıştır. Bu amaca yönelik olarak benimsediği eleştirel yaklaşım açısından, kaçınılmaz olarak Türkiye yanlısı bir makale olduğu eleștirisi gelecektir. Ancak burada vurgulanmak istenen asıl nokta, sorunun sadece Türkiye ve Kıbrıs'ın çifte vetolarının altını çizmekle giderilemeyeceğidir. Çünkü sorunun $A B$ ve NATO ile ilgili tarihsel ve yapısal başka dinamikleri vardır ve yalnızca bir ülkenin ayak diremesinin önüne geçilmesi ile çözülmesi de mümkün değildir. AB'nin üçüncü ülkelerle geliştirmiş olduğu ilişki şeklini yeniden gözden geçirmesi ihtiyacı ve özellikle savunma harcamalarının düştüğü küresel ekonomik kriz döneminde NATO içindeki Avrupacı ayrışmanın giderilmesi gerekliliği artık kaçınılamaz şekilde ortaya çıkmıştır.

Kıbrıs sorunu ileride çözülse bile, Avrupacı Müttefikler tutumlarını değiştirmediği sürece, NATO-AB ilişkilerindeki sorunlar ve çekişmeler devam edecektir. Gerek AB'nin gerekse NATO'nun bu bağlamda görmesi gereken, yeni küresel ortamda eski kısır yöntemlerle varlıklarını sürdüremeyecekleridir. Her iki örgüt de adaptasyon sürecine önce kendi içlerindeki sorunları çözerek başlamalıdır. OGSP açmazı da bu sorunlardan sadece biridir.

${ }^{47}$ Örnek: Maull (2005) ve (2006). 


\section{Kaynakça:}

Akgül Açıkmeşe, S. ve Triantaphyllou, D. (2012). The NATO-EU-Turkey trilogy: the impact of the Cyprus conundrum. Southeast European and Black Sea Studies, 12(4), 555-573.

Albright, M.K. (7 Aralik 1998). The right balance will secure NATO's future. Financial Times.

Alessandri, E. (2012). Transatlantic Relations Four Years Later: The Elusive Quest for a Strategic Vision. The International Spectator: Italian Journal of International Affairs. 47(3), 20-36.

Aykan, M.B., (2005). Turkey and European Security and Defence Identity/Policy (ESDI/P): A Turkish View. Journal of Contemporary European Studies, 13(3), 335-359.

Boulton, L. ve Dempsey J. (4 Aralık 2001). Turkey lifts its objection to EU rapid reaction force. Financial Times.

Buharal1, C. (2010). Better NATO-EU Relations Require more Sincerity", EDAM Discussion Paper Series, 2010/1. Erişim: 12 Mart 2010, http://www.gmfus.org/galleries/ct_ publication_attachments/NATOgmfedamNATOpaper.pdf.

Cascone, G. (2008) 'ESDP Operations and NATO - Cooperation, Rivalry or Muddling Through?', Michael Merlingen and Rasa Ostrauskaité (der.), European Security and Defence Policy: An Implementation Perspective. Londra ve New York: Routledge, 143158.

Cem, İ. (29 May1s 2001). A Necessary Role in Defence. Financial Times.

Council of the European Union (3-4 Haziran 1999). 'Presidency Conclusions, Cologne European Council', Erişim: 15 Temmuz 1999, http://www.consilium.europa.eu/ ueDocs/cms_Data/docs/pressData/en/ec/kolnen.htm.

Council of the European Union (10-11 Aralık 1999a). 'Annex I to Annex IV, Presidency Progress Report to the Helsinki European Council on Strengthening the Common European Policy on Security and Defence - Presidency Conclusions, Helsinki European Council'. Erişim: 12 Ocak 2000, http://www.consilium.europa.eu/uedocs/ cms_data/docs/pressdata/en/ec/ACFA4C.htm.

Council of the European Union (10-11 Aralık 1999b). 'Presidency Conclusions, Helsinki European Council', Erişim: 12 Ocak 2000, http://www.consilium.europa.eu/uedocs/ cms_data/docs/pressdata/en/ec/ACFA4C.htm.

Council of the European Union (19-20 Haziran 2000). 'Presidency Conclusions, Santa Maria Da Feira European Council', Erişim: 19 Temmuz 2000, http://www.consilium.europa. eu/ueDocs/cms_Data/docs/pressData/en/ec/00200-r1.en0.htm.

Council of the European Union (7-9 Aralık 2000). 'Presidency Conclusions, Nice European Council', Erişim: 30 Aralık 2000, http://www.consilium.europa.eu/uedocs/cms data/docs/pressdata/en/ec/00400-r1.\%20ann.en0.htm. 
Council of the European Union (26 Kasim 2002). 'Annex II - ESDP: Implementation of the Nice Provisions on the Involvement of the Non-EU European Allies, Presidency Conclusions, Brussels European Council, 24-25 Ekim 2002', 14702/02 POLGEN 67. Erişim: 15 Aralık 2002, http://www.consilium.europa.eu/uedocs/cms_data/docs/ pressdata/en/ec/72968.pdf.

Council of the European Union (29 Ocak 2003). 'Presidency Conclusions, Copenhagen European Council, 12-13 Aralık 2002', 15917/02 POLGEN 84. Erişim: 20 Şubat 2003, http://ec.europa.eu/research/era/docs/en/council-eu-27.pdf.

Del Sarto, R.A. ve Schumacher, T. (2005). From EMP to ENP: What's at Stake with the European Neighbourhood Policy towards the Southern Mediterranean? European Foreign Affairs Review, 10, 17-38.

Dempsey, J. (30 Mayıs 2001). Turkey agrees to use of NATO assets by EU force. Financial Times.

Dempsey, J. (11 Aralık 2001). Greece blocks EU accord with Nato. Financial Times.

Duke, S. (2008). The Future of EU-NATO Relations: a Case of Mutual Irrelevance Through Competition? European Integration, 30(1), 27-43.

European Commission (10 Ekim 2012). 'Commission Staff Working Document Turkey 2012 Progress Report Accompanying the Document Communication from the Commission to the European Parliament and the Council Enlargement Strategy and Main Challenges 2012-2013', $\operatorname{COM(2012)~} 600$ final, SWD(2012) 336 final. Erişim: 15 Ekim 2012, http://ec.europa.eu/enlargement/pdf/key_documents/2012/package/tr_rapport_2012_en.p df.

Fedyszyn, T. (2010). Saving NATO: Renunciation of the Article 5 Guarantee. Orbis, 54(3), 374-386.

Grabbe, H. (2006). The EU's Transformative Power:Europeanization through Conditionality in Central and Eastern Europe, Hampshire ve New York: Palgrave Macmillan.

Grant, C. (10 Eylül 2001). “A European View of ESDP”, IISS/CEPS European Security Forum için hazırlanmış bildiri, Erişim: 11 Haziran 2002 http://www.eusec.org/grant.htm.

Gürer, M. (27 Aralık 2011). Türk Askeri AB'den çekilebilir. Akşam. Erişim: 27 Aralık 2011, http://www.aksam.com.tr/turk-askeri-abden-cekilebilir--88540h.html.

Hoffmann, S. ve Reynolds, C. (2007). EU-NATO Relations: Time to Thaw the 'Frozen Conflict'. SWP Comments, 12. Erişim: 15 Şubat 2008, http://www.swp-berlin.org/ fileadmin/contents/products/comments/2007C12_hof_reyn_ks.pdf.

Howorth, J. (2009). NATO and ESDP: Institutional Complexities and Political Realities. Politique Étrangerè, 4, English Edition, 95-106.

Joyner, J. (25 Ağustos 2011). NATO fails in Libya. The National Interest. Erişim: 20 Ekim 2011, http://nationalinterest.org/commentary/nato-falls-libya-5802.

Kammel, Arnold ve Benjamin Zyla (2011). Looking for a 'Berlin Plus in Reverse'? NATO in Search of a New Strategic Concept. Orbis, 55(4), 648-662. 
Koenig, N. (2010). The EU and NATO: Towards a Joint Future in Crisis Management? EU Diplomacy Papers, 11/2010. Bruges: College of Europe, Department of EU International Relations and Diplomacy Studies. Erişim: 15 Mart 2011, http://aei.pitt.edu/15479/1/EDP_11_2010_Koenig.pdf.

Lachman, N. (2010). NATO-CSDP-EU Relations: Sketching the map of a community of practice. Working Paper, 34, Montreal: The Centre for International Peace and Security Studies (CIPSS). Erişim: $15 \quad$ Mart 2011, http://cepsicipss.ca/docs/publications/CIPSS\%20Working\%20Paper\%20Lachmann.pdf.

Manners, I. (2002). Normative Power Europe: A Contradiction in Terms? Journal of Common Market Studies, 40(2), 235-258.

Maull, H.W. (2005). Europe and the new balance of global order. International Affairs, 81(4), 775-799.

Maull, H.W. (2006).The Perils of NOT Conceiving EU Foreign Policy as a Civilizing Project. Internationale Politik und Gesellschaft, 1, 164-172.

Missiroli, A. (2002). EU-NATO Cooperation in Crisis Management: No Turkish Delight for ESDP. Security Dialogue, 33(1), 9-26.

NATO (16 Aralık 2002). 'EU-NATO Declaration on ESDP', Press Release (2002) 142. Erişim: 6 Ocak 2003, http://www.nato.int/docu/pr/2002/p02-142e.htm.

NATO (Kasım 2010). 'Strategic Concept for the Defence and Security of The Members of the North Atlantic Treaty Organisation - Active Engagement, Modern Defence'. Erişim: 13 Aral1k 2010, http://www.nato.int/lisbon2010/strategic-concept-2010-eng.pdf.

North Atlantic Council (24 Nisan 1999a). 'Washington Summit Communiqué - An Alliance for the 21st Century'. Erişim: 26 Mayıs 1999, http://www.nato.int/docu/pr/1999/p99064e.htm.

North Atlantic Council (24 Nisan 1999b). 'The Alliance's Strategic Concept'. Erişim: 26 Mayis 1999, http://www.nato.int/cps/en/natolive/official_texts_27433.htm?selected Locale $=$ en.

Ortega, M. (1998). 'Some Questions on Legal Aspects', Guido Lenzi (der.), WEU at Fifty. Paris: Institute for Security Studies, Western European Union, 1-13.

Öymen, O. (2001). Guest Editorial: Turkey and the New Challenges to European Security. European Foreign Affairs Review, 6(4), 401-405.

Papandreou briefs the TDN over the basic principles for the EU army: Both Ankara and Athens open for discussions over the ESDP. (27 Haziran 2002). Turkish Daily News.

Rasmussen, A.F. (Temmuz/Ağustos 2011). NATO after Libya - The Atlantic Alliance in Austere Times. Foreign Affairs. Erişim: 20 Ekim 2011, http://www.nato.int/cps/en/nato live/opinions_75836.htm.

Richmond, O. P. (2009). A post-liberal peace: Eirenism and the everyday. Review of International Studies, 35, 557-580.

Sarribrahimoğlu, L. (4 Aralık 2001). Turkish military compromise comes when NATO is at stake: Common sense prevails in Ankara over European Army. Turkish Daily News. 
Seidler, F.F. (3 Kasım 2011). Say Goodbye to Prestige Thinking: Quit CSDP and Concentrate on NATO. ATLANTIC-COMMUNITY.ORG. Erişim: 5 Kasım 2011, http://www.atlantic-community.org/index/Open_Think_Tank_Article/Say_Goodbye_ to_Prestige_Thinking\%3A_Quit_CSDP_and_Concentrate_on_NATO_.

Symanski, A. ve Terlikowski, M. (17 Kasim 2010). The Policy of Turkey towards EUNATO Cooperation. The Polish Institute of International Affairs (PISM) Bulletin, 133(209). Erişim, 20 Kasım 2011, http://www.pism.pl/index/?id=63eb58bd4d3486 f001438f911a11d323.

Türkiye, AB'ye Askeri Desteğini Geri Çekti. (7 Haziran 2007). Milliyet.com.tr, Erişim: 07 Haziran 2007, http://www.milliyet.com.tr/2007/06/07/son/sondun34.asp.

Ülgen, S. (2008).The Evolving EU, NATO and Turkey Relationship: Implications for Transatlantic Security. EDAM Discussion Paper Series, 2008/02. Erişim: 26 Haziran 2008, http://www.edam.org.tr/document/edam-discussion\%20paper2\%202008-seri.pdf.

Varwick, J. ve Koops, J. (2009). 'The European Union and NATO - 'Shrewd interorganizationalism' in the making?', Knud Erik Jorgensen (der.), The European Union and International Organizations. Londra ve New York: Routledge, 101-130.

WEU Secretariat-General (Ocak 2000). WEU Today. Brüksel. Erişim: 20 Kasım 2011, http://www.weu.int/WEU_Today2.pdf. 